\title{
A protocol for monitoring plant responses to changing nitrogen deposition regimes in Alberta bogs
}

\author{
Dale H. Vitt • Melissa House • Samantha Kitchen • \\ R. Kelman Wieder
}

Received: 20 April 2020 / Accepted: 28 September 2020 /Published online: 2 November 2020

(C) The Author(s) 2020

\begin{abstract}
Bogs are nutrient poor, acidic ecosystems that receive their water and nutrients entirely from precipitation (=ombrogenous) and as a result are sensitive to nutrient loading from atmospheric sources. Bogs occur frequently on the northern Alberta landscape, estimated to cover $6 \%$ of the Athabasca Oil Sands Area. As a result of oil sand extraction and processing, emissions of nitrogen $(\mathrm{N})$ and sulfur $(\mathrm{S})$ to the atmosphere have led to increasing $\mathrm{N}$ and $\mathrm{S}$ deposition that have the potential to alter the structure and function of these traditionally nutrient-poor ecosystems. At present, no detailed protocol is available for monitoring potential change of these sensitive ecosystems. We propose a user-friendly protocol that will monitor potential plant and lichen responses
\end{abstract}

Electronic supplementary material The online version of this article (https://doi.org/10.1007/s10661-020-08645-z) contains supplementary material, which is available to authorized users.

D. H. Vitt $(\bowtie) \cdot$ M. House $\cdot$ S. Kitchen

School of Biological Sciences, Southern Illinois University, Carbondale, IL 62901, USA

e-mail:dvitt@siu.edu

R. K. Wieder

Department Biology, Villanova University, Villanova, PA 19085, USA

\section{R. K. Wieder}

Center for Biodiversity and Ecosystem Stewardship, Villanova University, Villanova, PA 19085, USA

\section{R. K. Wieder}

Faculty of Science and Technology, Athabasca University, Athabasca, Alberta, Canada to future environmental inputs of nutrients and provide a structured means for collecting annual data. The protocol centers on measurement of five key plant/lichen attributes, including changes in (1) plant abundances, (2) dominant shrub annual growth and primary production, (3) lichen health estimated through chlorophyll/ phaeophytin concentrations, (4) Sphagnum annual growth and production, and (5) annual growth of the dominant tree species (Picea mariana). We placed five permanent plots in each of six bogs located at different distances from the center of oil sand extraction and sampled these for 2 years (2018 and 2019). We compared line intercept with point intercept plant assessments using NMDS ordination, concluding that both methods provide comparable data. These data indicated that each of our six bog sites differ in key species abundances. Structural differences were apparent for the six sites between years. These differences were mostly driven by changes in Vaccinium oxycoccos, not the dominant shrubs. We developed allometric growth equations for the dominant two shrubs (Rhododendron groenlandicum and Chamaedaphne calyculata). Equations developed for each of the six sites produced growth values that were not different from one another nor from one developed using data from all sites. Annual growth of $R$. groenlandicum differed between sites, but not years, whereas growth of $C$. calyculata differed between the 2 years with more growth in 2018 compared with 2019. In comparison, Sphagnum plant density and stem bulk density both had strong site differences, with stem mass density higher in 2019. When combined, annual production of $S$. fuscum was greater 
in 2019 at three sites and not different at three of the sites. Chlorophyll and phaeophytin concentrations from the epiphytic lichen Evernia mesomorpha also differed between sites and years. This protocol for field assessments of five key plant/lichen response variables indicated that both site and year are factors that must be accounted for in future assessments. A portion of the site variation was related to patterns of $\mathrm{N}$ and $\mathrm{S}$ deposition.

Keywords Allometric equation - Atmospheric deposition · Bog · Boreal · Nitrogen · Peatland · Oilsands . Sphagnum

\section{Introduction}

Bogs are Sphagnum-dominated, acidic, nutrient poor, peat-accumulating ecosystems found in subarctic, boreal, and cool-temperate regions, mainly in the northern hemisphere (Vitt 2006). In western Canada, they cover $365,157 \mathrm{~km}^{2}$ (or about 20\%) of the land surface in Alberta, Saskatchewan, and Manitoba (Vitt et al. 2000). Hydrologically, bogs are ombrogenous, receiving water and nutrient inputs only from atmospheric sources and have naturally low nutrient and base cation levels. In pristine areas, nutrient inputs are completely absorbed and utilized in growth by the plants and lichens occupying the bog ecosystem (Wieder et al. 2019). Species richness is low, and plant communities exhibit high species similarity across sites (Vitt et al. 1995a). All bogs in continental Canada have a canopy dominated by one tree species, Picea mariana, a shrub layer of 5-6 species of Ericaceae and dominated by either Rhododendron (Ledum) groenlandicum or Chamaedaphne calyculata, and a hummocky ground layer mostly dominated by one species of peat moss Sphagnum fuscum (Vitt et al. 1995a). Fruticose lichens (especially Evernia mesomorpha and Usnea spp.) are abundant on tree branches (Vitt 2006). These speciespoor plant communities are sensitive to environmental changes and, owing to their ombrogenous water source, are especially sensitive to nutrient loading from atmospheric sources (Wieder et al. 2019).

Research in European bogs has shown that increasing atmospheric nitrogen $(\mathrm{N})$ deposition leads to changes in ecosystem structure and function, including altered growth and species composition of Sphagnum mosses, increase in vascular plant abundances, increased $\mathrm{N}$ concentrations and quantities in peat, and increased $\mathrm{NH}_{4}{ }^{+}-$
$\mathrm{N}, \mathrm{NO}_{3}{ }^{-}-\mathrm{N}$, and/or dissolved inorganic $\mathrm{N}$ concentrations (DIN) in bog porewaters (e.g., Berendse et al. 2001; Bragazza and Limpens 2004; Bragazza et al. 2005; Gunnarsson and Rydin 2000; Gunnarsson et al. 2004; Hoosbeek et al. 2002; Lamers et al. 2000; Limpens and Berendse 2003; Limpens et al. 2003; Wiedermann et al. 2008). In eastern North America, at Mer Bleue bog in eastern Ontario, after 5 years of $\mathrm{N}$ fertilization, Bubier et al. (2007) reported an increase in vascular plant cover and decease in Sphagnum abundance. However, all of these studies were done in areas where ambient levels of $\mathrm{N}$ deposition have been significantly higher than those found in western Canada. In addition, many studies have shown that lichens, especially fruticose growth forms, are among the most sensitive components of vegetation to increasing $\mathrm{N}$ inputs (e.g., Gilbert 1986; Van Dobben et al. 2001).

The Oil Sands Administrative Area in northern Alberta occupies $140,329 \mathrm{~km}^{2}$ with bogs covering $6 \%$ of the area (Wieder et al. 2016b). Atmospheric deposition of $\mathrm{N}$ is low in the region $\left(<1 \mathrm{~kg} \mathrm{~N}^{-1}\right.$ year $^{-1}$; Hember 2018; Wieder et al. 2016a); however, oil sand development north of Fort McMurray, Alberta, has led to increasing $\mathrm{N}$ deposition with values as high as $17 \mathrm{~kg} \mathrm{~N} \mathrm{ha}^{-1}$ year $^{-1}$ (Fenn et al. 2015; Wieder et al. 2016a). These high values of atmospherically deposited $\mathrm{N}$ have the potential to alter the structure and function of these traditionally nutrient-poor ecosystems; however, no detailed protocol is available for monitoring potential change of these sensitive ecosystems. Although the Alberta Biodiversity Monitoring Institute has a province-wide program to track Alberta's wildlife and their habitats, and tracks the health of many species (ABMI 2017), the program is not designed to assess ecosystem changes on an annual basis. Furthermore, bogs are only a small part of their broad program. We are aware of only two studies that aimed to track the change of vegetation through time in wetland plant communities, and both of these determined vegetation change after restoration of bogs recovering from horticultural peat mining in eastern Canada (Poulin et al. 2013; Rochefort et al. 2013).

Previous research at a bog near Mariana Lakes, Alberta, experimentally added $\mathrm{N}$ over a 5 -year time period (at levels up to $25 \mathrm{~kg} \mathrm{~N}^{-1}$ year $^{-1}$, as $\mathrm{NH}_{4} \mathrm{NO}_{3}$ in simulated rainfall) At the higher levels, Sphagnum fuscum net primary production (NPP) was inhibited, dominant shrub and Picea mariana aboveground NPP were stimulated, with increased root biomass and 
production, and Sphagnum species relative abundance changed. Higher N deposition also increased the abundance of Rhododendron groenlandicum and Andromeda polifolia and to vascular plants in general, with an increase in shrub leaf $\mathrm{N}$ concentrations in Andromeda polifolia, Chamaedaphne calyculata, Vaccinium oxycoccos (=Oxycoccus microcarpus), V. vitis-idaea, and Picea mariana (Wieder et al. 2019). Of fundamental importance to the $\mathrm{N}$ cycle in bogs, this research showed that biological $\mathrm{N}_{2}$-fixation greatly exceeded atmospheric $\mathrm{N}$ deposition as a source of new $\mathrm{N}$ inputs to the bog; however, an increase in $\mathrm{N}$ addition stimulated $\mathrm{N}_{2}$-fixation at deposition $<3.1 \mathrm{~kg} \mathrm{~N}^{-1}$ year $^{-1}$ and progressively inhibited $\mathrm{N}_{2}$-fixation as $\mathrm{N}$ deposition increased above this level.

These unique attributes of bogs (e.g., ombrotrophy) and their responses to environmental conditions from atmospheric deposition make them target ecosystems for monitoring changes in atmospheric inputs of nutrients. In particular, $\mathrm{N}$ inputs are a primary stressor of concern in many regions affected by anthropogenic disturbances (Galloway et al. 2008; Kanakidou et al. 2016). Here we propose a multi-faceted user-friendly approach designed to monitor plant/lichen responses to changing atmospheric deposition regimes in bogs utilizing five key components of bog ecosystems. Indicators were selected based on the following criteria: (1) responsive to stressors, (2) costeffective, (3) repeatable, and (4) have species and community features that are easy to quantify and identify by field personnel with a moderate level of taxonomic expertise. Although species in the genus Sphagnum are thought to be taxonomically difficult, only three species commonly occur in Alberta bogs, and these are easily differentiated by color alone. Data for all of these indicators are easily collected in the field and analyzed in the laboratory at minimal cost. Our primary objective was to develop a monitoring protocol for assessing key parameters of bog ecosystems that are appropriate for long-term permanent monitoring stations. Our objectives were centered around six questions. (1) For the plant community-over a multiyear time frame with different field personnel, is a line transect method of plant abundance assessment appropriate for monitoring? (2) Can a line transect with numerous contiguous points of measurement be reduced to a more limited point transect method? (3) For plant growth and production - can we develop an easy, non-destructive, field-based method for assessing plant annual growth and production utilizing the 1-2 dominant shrub species present at each site? (4) Using only one lichen species
(Evernia mesomorpha), can we develop a suitable technique for using lichen chlorophyll/phaeophytin ratios as an indicator of lichen health? (5) Using cranked wires how variable is annual growth and NPP of Sphagnum? (6) Can we use leader length of Picea mariana to assess variability in growth of this species? Here we assess the outcomes of these protocols over a 2-year time period for a series of six bog sites in northeastern Alberta, Canada, and provide evidence of whether the variability in responses can be related to growing season $\mathrm{N}$ and $\mathrm{S}$ deposition from oil sands activities.

\section{Materials and methods}

Site selection

Peat-forming wetlands (bogs and fens) are a major feature of Alberta's landscape (Vitt et al. 1995b) and cover 6\% and $21 \%$, respectively, of the $140,329 \mathrm{~km}^{2}$ Oil Sands Administrative Area in northeastern Alberta (Wieder et al. 2016a). We chose six bog sites (Table 1), centered on the Syncrude/Suncor Canadian oil sands active openpit mines and refineries, north of Fort McMurray, Alberta. Sites ranged from 12 to $77 \mathrm{~km}$ from oil sands refineries. All bogs have attributes described by Belland and Vitt (1995) and are characterized as follows: a tree canopy of mature (from 69 to 82 years old (to 2019) Picea mariana, a shrub layer of Rhododendron groenlandicum, Chamaedaphne calyculata, Vaccinium oxycoccos, V. vitis-idaea, and Kalmia polifolia, a forb layer of Rubus chamaemorus and Maianthemum (Smilacina) trifolium, and a ground layer of $100 \%$ mosses dominated by Sphagnum fuscum, with occasional hummocks of Pleurozium schreberi and S. capillifolium and lawns of $S$. angustifolium. The lichen, Evernia mesomorpha, is abundant on tree branches. At the top of the bog water table, porewater mean $\mathrm{pH}$ at these six bog sites ranged from 3.81 to 4.69 and mean reduced (corrected for $\mathrm{pH}$ ) electrical conductivity ranged from 18 to $131 \mu \mathrm{S} \mathrm{cm}$. Regional climate is characterized by $164-221 \mathrm{~mm}$ growing season precipitation, a mean July daily temperature of $14.5-15.1^{\circ} \mathrm{C}$, and a growing season aridity index (PET/ Precipitation) of 1.7-2.6 (Wieder et al. 2016b).

\section{Sampling design}

At each of the six bog sites, we used a restricted random design and placed five plots approximately 30-60 m 
apart. Each plot contained a 300-cm-long transect placed in a large hummock of Sphagnum fuscum, two $1-\mathrm{m}^{2}$ shrub abundance plots, a meandering transect for collecting biomass of Evernia mesomorpha, and 10 randomly chosen Picea mariana trees for leader length measurement. All bogs had an open canopy, and individual trees from 1 to $2 \mathrm{~m}$ tall were chosen and marked with aluminum tags.

\section{Plant community composition}

Reviews of sampling methods for plant abundances are found in McCune and Grace (2002) and Phillips (1959). We considered several alternatives for sampling. Releve's (Braun-Blanquet 1932) are based on lists of species with visual estimation of cover within an area of homogenous vegetation. Cover estimates are potentially biased by different observers and require a thorough knowledge of the regional flora. Comparatively, the point-observation methods yield an estimate of cover of each species in a standardized plot (Clements 1905). These plots may be fixed contiguously along a transect, randomly placed along a transect, or restricted to transect segments, and often have nested subplots for different sized vegetation units. Both methods suffer from over-estimates in the cover of rare species and yield imprecise estimates of the more abundant species, especially since repeated measurements are usually done on the same plots by different observers. Another method that provides repeatable data is the line-intercept method (Canfield 1941) that uses percent cover as a proportion of the total length of each species along a line in comparison with the total length of the line. Although the line-intercept method provides a rich set of data, it suffers from being relatively tedious and timeconsuming in data collection. The point-intercept

Table 1 Locations of six bog sites used in this study. Distance refers to distance from midpoint between Syncrude Canada and Suncor refinery stacks $(\mathrm{km})$

\begin{tabular}{llll}
\hline Site & Latitude & Longitude & Distance \\
\hline JPH4 & $57^{\circ} 06^{\prime} 45^{\prime \prime} \mathrm{N}$ & $111^{\circ} 25^{\prime} 23^{\prime \prime} \mathrm{W}$ & 12 \\
McKay & $57^{\circ} 13^{\prime} 41^{\prime \prime} \mathrm{N}$ & $111^{\circ} 42^{\prime} 11^{\prime \prime} \mathrm{W}$ & 24 \\
Kearl & $57^{\circ} 19^{\prime} 04^{\prime \prime} \mathrm{N}$ & $111^{\circ} 13^{\prime} 07^{\prime \prime} \mathrm{W}$ & 32 \\
McMurray & $56^{\circ} 37^{\prime} 37^{\prime \prime} \mathrm{N}$ & $111^{\circ} 11^{\prime} 44^{\prime \prime} \mathrm{W}$ & 49 \\
Anzac & $56^{\circ} 28^{\prime} 08^{\prime \prime} \mathrm{N}$ & $111^{\circ} 02^{\prime} 34^{\prime \prime} \mathrm{W}$ & 69 \\
Horse Creek & $56^{\circ} 19^{\prime} 46^{\prime \prime} \mathrm{N}$ & $111^{\circ} 35^{\prime} 22^{\prime \prime} \mathrm{W}$ & 77 \\
\hline
\end{tabular}

method (Goodall 1953) provides a data set of frequency values for points placed along a line; it takes less time to complete but may provide a less detailed data set that may not include the full suite of species found along the transect. Points can be randomly chosen or systematically placed along the line. Both line-intercept and point-intercept methods use absolute frequency, or the proportion of occurrences of a species relative to the number of sample units taken along the line transect.

We used a 300-cm-long line transect, with the transect usually divided into two portions in order to fit on a single large Sphagnum hummock, to characterize vascular plant, bryophyte, and lichen community composition. Sphagnum hummocks were chosen from among those dominated by S. fuscum (or S. capillifolium in one case) without evidence of disturbance. For each transect, permanent, plastic survey stakes were placed at the ends and the transect delineated by a cloth measuring tape held straight and anchored at ground level by the stakes at each end of the transect. Species presence was recorded at every centimeter along the $300-\mathrm{cm}$ line. A ruler, kept vertically straight, was used to assist in determining whether a living vascular plant, bryophyte, or ground lichen was present or absent at a given point. Data were not transformed and were analyzed as absolute frequency (number of hits/300). In order to determine if pointintercept data would mirror the data from the $300 \mathrm{~cm}$ line transect, frequency data from 30 and 60 evenly spaced points along the transect were extracted and compared with the 300-point line transect.

Lichen chlorophyll and phaeophytin

Approximately 30-40 thalli of the lichen Evernia mesomorpha were collected from each plot in paper bags. Lichen thalli were dried at room temperature and kept at $-20{ }^{\circ} \mathrm{C}$ until chlorophyll and phaeophytin analysis. Prior to analysis, $20 \mathrm{mg}$ of lichen tissue (tissue taken from the apical parts of the thalli) were taken from 10 randomly selected thalli for each plot, for a total of 50 samples per site. To extract chlorophyll and determine percent phaeophytin, samples were extracted using dimethyl sulfoxide (DMSO). Acetone has also been used for this extraction (Arnon 1949; Barnes et al. 1992). The DMSO method can be used with fresh, not ground, tissue and has been found to be comparable to the acetone method (Ronen and Galun 1984; Barnes et al. 1992; Tait and Hik 2003). Using test tubes, $5 \mathrm{~mL}$ of dimethyl sulfoxide (DMSO) was added to 10 samples of 
lichen tissue at a time to extract chlorophyll (Ronen and Galun 1984). After incubating the 10 samples for $45 \mathrm{~min}$ at $60{ }^{\circ} \mathrm{C}$, another $5 \mathrm{~mL}$ of DMSO were added to each sample. Samples were transferred to a cuvette and analyzed on a spectrophotometer at 415, 433, 645, and $665 \mathrm{~nm}$ to measure optical density (OD). Chlorophyll $a$ and $b$ concentrations were calculated using the equation (Arnon 1949; Tait and Hik 2003):

mg chlorophyll g ${ }^{-1}$ air dry weight

$$
=\frac{\left(20.2 *\left(\mathrm{OD}_{645}\right)+8.02 *\left(\mathrm{OD}_{665}\right)\right) * 10 \mathrm{~mL}}{1000 \mathrm{~mL} * \mathrm{~g} \text { air-dry weight }}
$$

To determine chlorophyll degradation and the percent of phaeophytin, we used the ratio of OD at 433:415 or the ratio of chlorophyll $a$ to phaeophytin $a$ pigments. Using an $\mathrm{OD}_{433}: \mathrm{OD}_{415}$ curve (Ronen and Galun 1984), we used the following equation to calculate the chlorophyll $a$ to phaeophytin $a$ ratio:

\%phaeophytin $a=-104.8 \ln ($ OD433 : OD415) +39.715

Aboveground shrub growth (MPS) and aboveground NPP

We know of no information on predicting net primary production for bog shrubs using nondestructive sampling and allometric equations except for that in Wieder et al. (2019). Connolly and Grigal (1983) in Minnesota and $\mathrm{He}$ et al. (2018) in Alberta published allometric equations for fen shrub biomass, but none of the species utilized is found in bogs. To determine annual growth and aboveground net primary production (NPP) for the dominant two shrubs at each site, we destructively sampled new growth segments (shoots with leaves) from Rhododendron groenlandicum and Chamaedaphne calyculata. In July 2019, we collected 20 new growth segments (new growth from the most recent bud scar) of the two dominant species at each of five plots - outside of our $1-\mathrm{m}^{2}$ quadrats - for the six sites to develop allometric equations as a means for non-destructive estimation of NPP. After drying the growth segments at $55^{\circ} \mathrm{C}$ for 1 week, we quantified dry mass and determined the mass per new growth segment (MPS). For each new growth segment, we measured the shoot length $(\mathrm{mm})$, the number of leaves, and the length and maximum width $(\mathrm{mm})$ of each leaf. During the drying process, $R$. groenlandicum leaves slightly curled, thus affecting leaf width measurements. Using measurements of living
R. groenlandicum leaves from our 2018 and 2019 field data, we were able to predict the width and area of dried $R$. groenlandicum leaves:

$\mathrm{LA}=0.2798 \times \mathrm{LL}^{1.8156} ; R^{2}=0.87$

where LA is the leaf area $\left(\mathrm{mm}^{2}\right)$ and LL is the leaf length $(\mathrm{mm})$,

$\mathrm{LW}=\frac{4 \times L A}{L L \times \pi}$

and LW is the leaf width (mm), LA is the leaf area $\left(\mathrm{mm}^{2}\right)$, and LL is the leaf length (mm). Adapted from Wieder et al. (2019), we developed allometric growth equations that gave the best linear fit to determine MPS (mg segment $^{-1}$ ) for $R$. groenlandicum and C. calyculata at each site (Table 2). We used the modeled MPS and density of shoots for each species to calculate NPP.

Net primary production (NPP) of Sphagnum fuscum is the product of linear growth of stems $\left(\mathrm{cm} \mathrm{year}^{-1}\right)$ and stem mass density (SMD), with SMD defined as the mass of 1-cm lengths of Sphagnum stems beneath the capitula per square meter. We used the cranked wire method (Clymo 1970; Vitt 2007) to measure linear growth of Sphagnum fuscum. We set 30 cranked wires in each of the five plots, with all wires placed in hummocks dominated by S. fuscum. Annually, we set cranked wires in early May (after ice thawed from the upper peat) and remeasured them in late September or early October. To measure SMD, we collected surface cores $(6.5 \mathrm{~cm}$ diam.) from $S$. fuscum hummocks in each plot in early July of each year. From each core, all capitula were removed and counted to determine S. fuscum plant density (plants $\mathrm{m}^{2}$ ). Seventy stems of S. fuscum were selected, cut into 2-cm lengths, and weighed after drying at $55{ }^{\circ} \mathrm{C}$ for 5 days. SMD was calculated as the average mass of a $1-\mathrm{cm}$ stem of an individual Sphagnum plant multiplied by plant density.

\section{Leader length of Picea mariana}

Bogs of the region are dominated by a single tree species Picea mariana (black spruce). Stand dynamics of this species have been examined by Wieder et al. (2009). Mature bogs of the region are mostly less than 100 years old, and stand replacement is largely by wildfire. In July 2019, ten Picea mariana trees were selected along a transect at each plot. Leader length (or terminal leader extension) for one growing season was quantified by 
Table 2 Best linear fit parameters and $r^{2}$ values for equations relating $\mathrm{mg}$ per new growth segment (MPS; g dry mass per segment) to average leaf length (ALL, mm), average leaf width (ALW, mm), average segment length
(ASL, mm), and average number of leaves per segment (ALPS; \# per segment), using the following general equation: $\mathrm{MPS}=a \times \sqrt{(0.5 \times \mathrm{ALL} \times 0.5 \times \mathrm{ALW} \times \pi \times \mathrm{ASL} \times \mathrm{ALPS}})+b$.

\begin{tabular}{|c|c|c|c|c|}
\hline & \multirow[b]{2}{*}{ Site } & \multicolumn{3}{|c|}{ Parameter estimates } \\
\hline & & $a$ & $b$ & $R^{2}$ \\
\hline \multirow[t]{7}{*}{ R. groenlandicum } & JPH4 & 0.0011 & 0.0044 & 0.86 \\
\hline & McKay & 0.0009 & 0.0134 & 0.85 \\
\hline & Kearl & 0.0012 & -0.0092 & 0.86 \\
\hline & McMurray & 0.0012 & -0.0047 & 0.88 \\
\hline & Anzac & 0.0009 & 0.0283 & 0.80 \\
\hline & Horse Creek & 0.0012 & -0.0118 & 0.90 \\
\hline & All sites combined & 0.0010 & 0.0057 & 0.85 \\
\hline \multirow[t]{7}{*}{ C. calyculata } & JPH4 & 0.0005 & -0.0065 & 0.94 \\
\hline & McKay & 0.0004 & 0.0012 & 0.91 \\
\hline & Kearl & & & \\
\hline & McMurray & 0.0005 & -0.0027 & 0.89 \\
\hline & Anzac & 0.0005 & -0.0038 & 0.91 \\
\hline & Horse Creek & 0.0005 & -0.0107 & 0.91 \\
\hline & All sites combined & 0.0005 & -0.0032 & 0.91 \\
\hline
\end{tabular}

measuring from the second most recent bud scale to the most recent bud scale, thus our data for leader length are for the 2018 growing season.

\section{Data analyses}

Analyses for plant community composition were based on absolute frequency data from each plot from each site. To determine differences between sites and changes in plant community composition between years, we used Bray-Curtis similarity nonmetric multidimensional scaling (NMDS) in Primer 7 (Clarke and Gorley 2006) with 100 restarts and no pretreatment of the data. A 2way PERMANOVA was used to determine differences between years and sites (fixed factors). For factors with significant differences, post hoc pair-wise tests were used to determine which sites and years differed.

To determine whether point-intercept data could replace our line-transect method, we used subsets of data from points located every $5 \mathrm{~cm}$ (60 points along the transect) and at every $10 \mathrm{~cm}$ (30 points along the transect). Within each year (2018 and 2019), we used a oneway PERMANOVA to test whether the subsets differed from the entire transect $(30,60$, and 300 points [fixed effect]).
Statistical analyses for Evernia mesomorpha chlorophyll $a$ and phaeophytin $a$ concentrations, aboveground Rhododendron groenlandicum and Chamaedaphne calyculata abundance, MPS and NPP, and Picea mariana leader length were performed in JMP (JMP v. Pro 14.3.0). Picea mariana leader length was tested between sites using a one-way nested (subsamples nested within plots) analysis of variance (ANOVA) design and Tukey's pairwise post hoc comparisons when data passed the Shapiro-Wilks test for normality $(p<0.05$ failure and visual inspection of residuals). Evernia mesomorpha chlorophyll and phaeophytin were analyzed using a two-way ANOVA (site, year as fixed effects) with subsamples nested within plot (random effect) and with Tukey's pairwise post hoc comparisons. Shrub abundance, MPS, and NPP were analyzed using a two-way ANOVA (site, year; fixed effects) with subplots nested within plots (random effect) and Tukey's pairwise post hoc comparisons when data passed the Shapiro-Wilks test for normality $(p<0.05$ failure and visual inspection of residuals). Non-normal data were either square-root (2018 vs. 2019 Rhododendron groenlandicum predicted NPP), cube-root (Evernia mesomorpha chlorophyll concentrations and percent phaeophytin, Rhododendron groenlandicum 
predicted MPS vs. dry weight), or log-transformed (2018 vs. 2019 Rhododendron groenlandicum predicted MPS, Picea mariana leader length) to improve homoscedasticity. To compare the site-specific MPS algorithms with the overall algorithm, ANCOVA was used to test for differences in slopes (SAS v.9.4).

Sphagnum fuscum plant density and stem mass density were assessed with a two-way ANOVA, with year and site as the main effects; a posteriori means comparisons were carried out using Tukey's HSD. The multiple cranked wires were treated as subsamples within each of the five replicate plots at each site. Thus, both linear growth and annual NPP (linear growth $\times$ stem mass density) were analyzed with a nested ANOVA; a posteriori means comparisons were carried out using Tukey's HSD. For linear growth and NPP, we report means \pm standard errors of the plots ( $n=5$ per site), not of the individual cranked wires.

We used atmospheric deposition data for 2018-2019 growing seasons from R. K. Wieder (Villanova University, unpublished data) for JPH4, McKay, McMurray, Anzac, Horse Creek, and Kearl. Deposition data from the six sites were collected using ion exchange resin collectors (Fenn et al. 2002, 2003) with methods described in Wieder et al. 2016b. We examined possible relationships between structural and functional response variables as a function of $\mathrm{NH}_{4}{ }^{+}-\mathrm{N}, \mathrm{NO}_{3}{ }^{-} \mathrm{N}, \mathrm{DIN}$, $\mathrm{SO}_{4}{ }^{-2}-\mathrm{S}$, and distance from the midpoint between the Syncrude and Suncor upgrader stacks using linear regression.

\section{Results}

Plant community composition

\section{Species diversity}

We recorded a total of 22 species from our plots located on S. fuscum hummocks at the six bog sites, 11 were vascular plants, 10 bryophytes (with 4 Sphagnum species), and one lichen. About $41 \%$ of the species were found at all six sites; similarity for vascular plants was high with eight of the vascular plants found at all sites, but low for bryophytes, with only one species occurring at all sites (Table 3). Mean alpha (plot) diversity was high (15.5), and beta diversity (species turnover between plots) was low (1.42).
Structural differences among sites and years

The years (2018 and 2019) differed (pseudo- $F=9.546$, $p=0.001$ ), and sites differed (pseudo- $F=9.984, p=$ 0.001 ). The six sites all differed from one another (post hoc pairwise test, $p<0.05$ ). Differences between sites are evident on the NMDS ordination (Fig. 1), with individual sites clustered at different locations on the ordination (Kearl plots are positioned to the upper center, McKay to the upper-right, Anzac to the lower right, McMurray center, Horse Creek to the left center, and JPH4 to the center and lower left). Plots at Anzac and two plots at JPH4 are most dissimilar, while plots from the 2 years $(2018,2019)$ cluster together. Differences in dominant species at the sites are evident on the ordination for a number of species (species vectors in Figs. 1 and 4 and on Online resource 1A-H) including Chamaedaphne calyculata (OR1A) - most abundant to the lower right at some Anzac and McMurray plots, Kalmia polifolia (OR1B) - abundant to the lower right at other Anzac plots, and Rhododendron groenlandicum (OR1C) - more abundant to the upper portion of the ordination at Kearl, McKay, and Horse Creek. Likewise, Vaccinium oxyxoccos is more abundant at these latter sites (upper portion of ordination) (Fig. OR1D). Pohlia nutans (Fig. OR1E) and Rubus chamaemorus (Fig. OR1F) are most abundant at McKay (to the upper right). Two plots at JPH4 were dominated by Sphagnum angustifolium (Fig. OR1G), while all others had S. fuscum as the dominant moss (Fig. OR1H). When all six sites are considered together, abundance of Rhododendron groenlandicum was 1.2 times higher than the combined abundances of Chamaedaphne calyculata, Kalmia polifolia, and Andromeda polifolia $(F=35.41, p<0.001)$.

\section{Structural differences between years}

Attributes contributing to between year differences include the following: all sites recorded less vascular plant cover in 2019 ranging from 17 (Anzac) to 34\% (McMurray) lower vascular plant abundance; these higher 2018 values were largely due to differences in estimates of Vaccinium oxycoccos frequency (overall = $51 \%$; ranging from 34 (JPH4) to 52\% (Horse Creek and McKay) of the overall dissimilarity between years). Dominant shrub species contributed to the overall dissimilarity-with $R$. groenlandicum (16\%), C. calyculata (8\%), and K. polifolia (4\%) higher in 
Table 3 List of species and occurrence (+) at the six bog sites for 2018 and 2019. Nomenclature: Cladonia= Cladina; Rhododendron $($ Rhodo. $)=$ Ledum; Maianthemum $=$ Smilacina $;$ Vaccinium oxycoccos $=$ Oxycoccus microcarpus

\begin{tabular}{|c|c|c|c|c|c|c|c|c|c|c|c|c|}
\hline \multirow[t]{2}{*}{ Species name } & \multicolumn{2}{|l|}{ Anzac } & \multicolumn{2}{|c|}{ Horse Creek } & \multicolumn{2}{|l|}{ JPH4 } & \multicolumn{2}{|l|}{ Kearl } & \multicolumn{2}{|c|}{ McKay } & \multicolumn{2}{|c|}{ McMurray } \\
\hline & 2018 & 2019 & 2018 & 2019 & 2018 & 2019 & 2018 & 2019 & 2018 & 2019 & 2018 & 2019 \\
\hline Andromeda polifolia & + & + & + & - & - & - & - & - & - & - & - & - \\
\hline Aulacomnium palustre & - & - & - & - & + & + & + & + & - & + & - & - \\
\hline Chamaedaphne calyculata & + & + & + & + & + & + & + & - & + & + & + & + \\
\hline Cladonia mitis & - & - & + & + & - & - & - & - & - & - & - & - \\
\hline Dicranum undulatum & - & - & - & - & - & - & + & + & - & - & - & - \\
\hline Drosera rotundifolia & + & + & + & + & + & + & + & + & + & + & + & + \\
\hline Eriophorum vaginatum & + & + & - & - & + & + & - & - & + & + & + & + \\
\hline Kalmia polifolia & + & + & + & + & + & + & + & + & + & + & + & + \\
\hline Mylia anomala & + & + & + & + & - & - & + & + & + & - & + & + \\
\hline Vaccinium oxycoccos & + & + & + & + & + & + & + & + & + & + & + & + \\
\hline Picea mariana & + & + & + & + & + & + & + & + & + & + & + & + \\
\hline Pleurozium schreberi & - & - & + & + & + & + & + & + & + & + & - & - \\
\hline Pohlia nutans & - & - & - & - & + & + & + & + & + & + & + & + \\
\hline Polytrichum strictum & - & - & - & - & + & + & + & + & + & + & + & + \\
\hline Rhodo. groenlandicum & + & + & + & + & + & + & + & + & + & + & + & + \\
\hline Rubus chamaemorus & - & + & + & + & + & + & + & + & + & + & + & + \\
\hline Maianthemum trifolium & + & + & - & - & - & - & + & + & + & + & + & + \\
\hline Sphagnum angustifolium & + & + & - & - & + & + & + & + & - & - & - & - \\
\hline Sphagnum capillifolium & - & - & - & - & + & + & - & - & - & - & - & - \\
\hline Sphagnum fuscum & + & + & + & + & + & + & + & + & + & + & + & + \\
\hline Sphagnum magellanicum & + & + & - & - & + & + & - & - & + & + & - & - \\
\hline Vaccinium vitis-idaea & + & + & + & + & + & + & + & + & + & + & + & + \\
\hline
\end{tabular}

2018. Also, $R$. groenlandicum abundances were different between years $(F=4.58, p=0.038)$, but C. calyculata did not differ between the 2 years $(F=$ 1.06, $p=0.308$ ) (Figs. 2 and 3). Site differences are evident as seen in Kearl (along with JPH4) having more and Anzac less abundance of R. groenlandicum (Fig. 2), while Kearl had much less C. calyculata (Fig. 3). Although senior field personnel overlapped between the 2 years, plot assessments were carried out by different personnel over similar time periods (July 10-17, 2018; July 14-19, 2019).

\section{Differences in species abundances}

between point-intercept and line transect assessment methods

Plot locations based on 30 and 60 points and those from data extracted from the $300-\mathrm{cm}$ line transect for 2018 (not shown) and 2019 cluster close together on the
NMDS ordination (Fig. 4). Similar to the line transect data, both the 30- and 60-point subsets revealed that the six bog sites were different from one another $(p<0.05)$. The subsets of 30 and 60 points also were not different from one another or the complete 300-point set (pseudo$F=0.256, p=0.985)$.

Lichen chlorophyll and phaeophytin

Chlorophyll $a$ and $b$ concentrations for Evernia mesomorpha differed between sites $(F=79.240$, $p<0.001)$, and year $(F=58.948, p<0.001)$, with interactions between site and year $(F=7.701, p<0.001)$. Overall, E. mesomorpha at Anzac (2019), JPH4, and McMurray had greater chlorophyll concentrations than at the remaining three sites. Chlorophyll concentrations were greater in 2019 than in 2018 at Anzac, and Horse Creek (Fig. 5). 
Fig. 1 NMDS ordination of plant community composition for 2018 (18) and 2019 (19). Sites are designated by color and shape, and years are distinguished by color fill or + vs. x. Vectors describing species abundance patterns are shown as lines radiating from a common origin, offset to left of center of the ordination (Clarke \& Gorley 2006). $A N=$ Anzac, $H C=$ Horse Creek, $J P=\mathrm{JPH} 4, K E=$ Kearl, $M K=$ McKay, $M M=$ McMurray

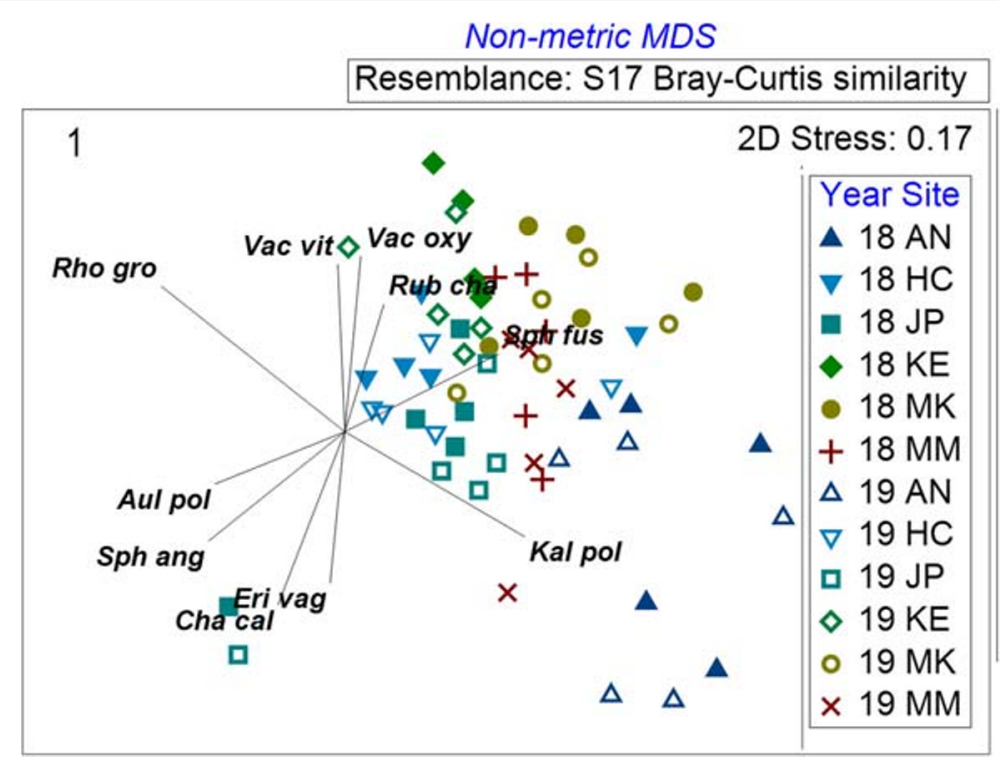

Percent phaeophytin $a$ in E. mesomorpha also differed between sites $(F=42.750, p<0.0001)$ and year $(F=10.151, p<0.0001)$, with interactions between site and year $(F=15.172, p<0.001)$ Although percent phaeophytin $a$ was greater in 2018 than 2019 overall (Fig. 6), this difference was driven by one site (Anzac), with the remaining five sites either not different or the reverse (2019 greater than 2018 at McKay). When sites are compared, E. mesomorpha at Anzac (2018), Horse Creek,
Kearl, and McKay (2019) had the highest percent phaeophytin contents.

The ratio of chlorophyll $a$ to phaeophytin $a$ in E. mesomorpha differed between sites $(F=43.283$, $p<0.001)$, and year $(F=8.753, p=0.003)$, with interactions between site and year $(F=16.250, p<0.0001)$. High ratios were recorded at Anzac (2019), JPH4, McKay (2018), and McMurray (2019). Ratios between years were only different at Anzac (2019) and McKay (2019) (Fig. 7).
Fig. 2 Mean ( \pm S.E.) abundance (as absolute frequency) of Rhododendron groenlandicum for 2018 and 2019 along the 300 $\mathrm{cm}$ line transect. Result is from a two-way ANOVA for year and site $(p<0.05)$, with different letters indicating significantly different values between sites (Tukey's pairwise post-hoc test at $p=<0.05)$. $M c M=$ McMurray

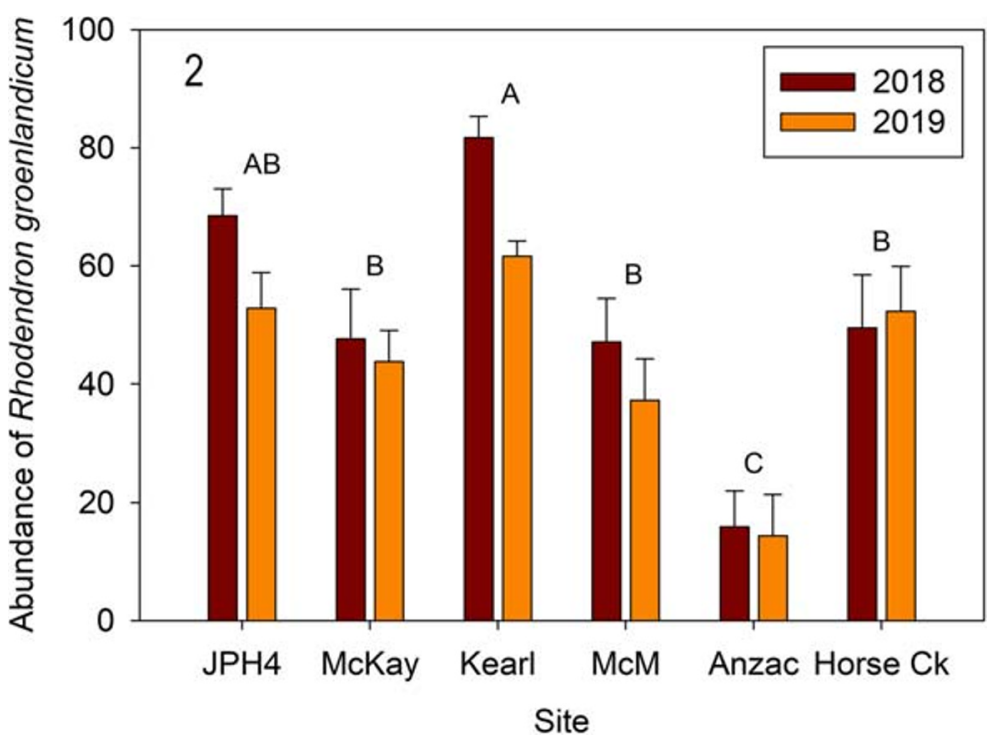

Springer 
Fig. 3 Mean ( \pm S.E.) abundance (as absolute frequency) of Chamaedaphne calyculata for 2018 and 2019 along the $300 \mathrm{~cm}$ line transect. Different letters indicate significantly different values $(p<0.05$ Tukey's test). $M c M=$ McMurray

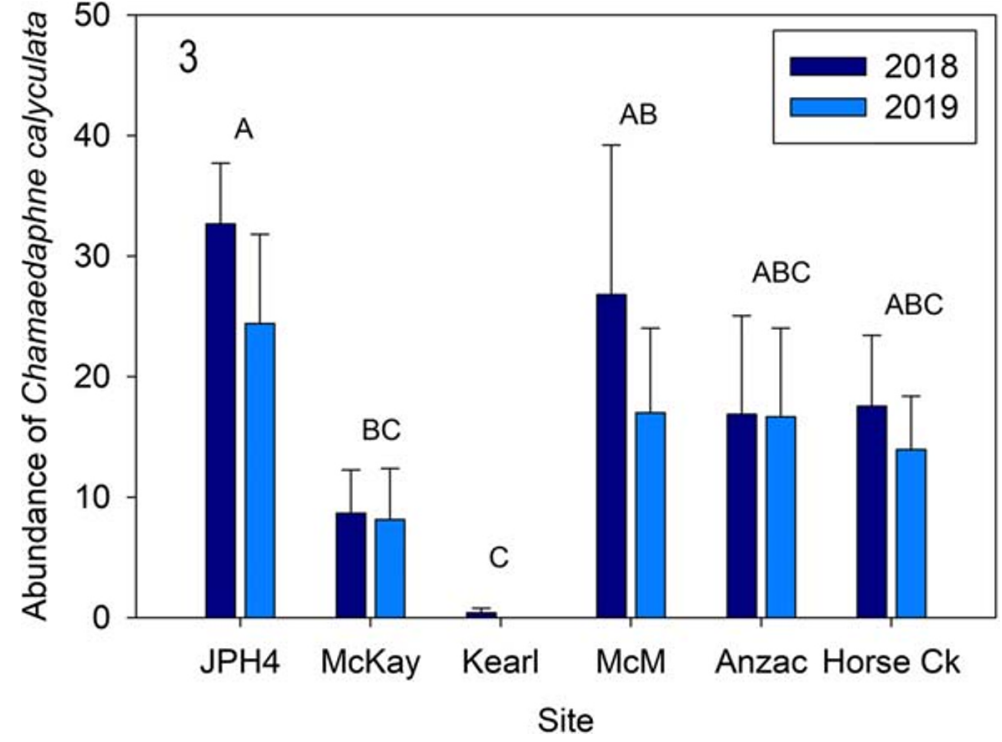

Dominant shrub MPS and aboveground NPP

\section{Rhododendron groenlandicum MPS and NPP}

Slopes for allometric growth equations modeled for each of the six sites were not different from one another or from the combined algorithm for 2019 (ANCOVA, $F=1.65, p=0.158)$. A comparison between the predicted MPS (using the combined allometric equation) and actual dry weight (mass type) for $R$. groenlandicum (for 2019) revealed that site $(F=5.683, p<0.0001)$ and the interaction between site and mass $(F=4.837, p=$ 0.0003 ) were significant, while mass type was not $(F=2.452, p=0.118)$. Predicted MPS and actual dry weight were not different from one another except for Kearl (Fig. 8), where predicted MPS was 1.8 times higher than the actual dry weight $(p<0.001)$.

Overall, $R$. groenlandicum predicted MPS was different between 2018 and $2019(F=4.467, p=0.040)$, between sites $(F=10.961, p<0.0001)$, and as interaction was detected between site and year $(F=16.220, p<0.0001)$. Sites JPH4 and Kearl were different between 2018 and 2019 and
Fig. 4 NMDS ordination of plant community composition for 2019 comparing similarities for data from the 30- and 60-point intercept analyses to the $300-\mathrm{cm}$ line transects. Sites are designated by color and shape, and subsets are distinguished by color and color fill. Vectors describing species abundance patterns are shown as lines radiating from a common origin, offset to left of center of the ordination (Clarke \& Gorley 2006). $A N=$ Anzac, $H C=$ Horse Creek, $J P=\mathrm{JPH} 4, K E=$ Kearl, $M K=$ McKay, $M M=$ McMurray
Non-metric MDS

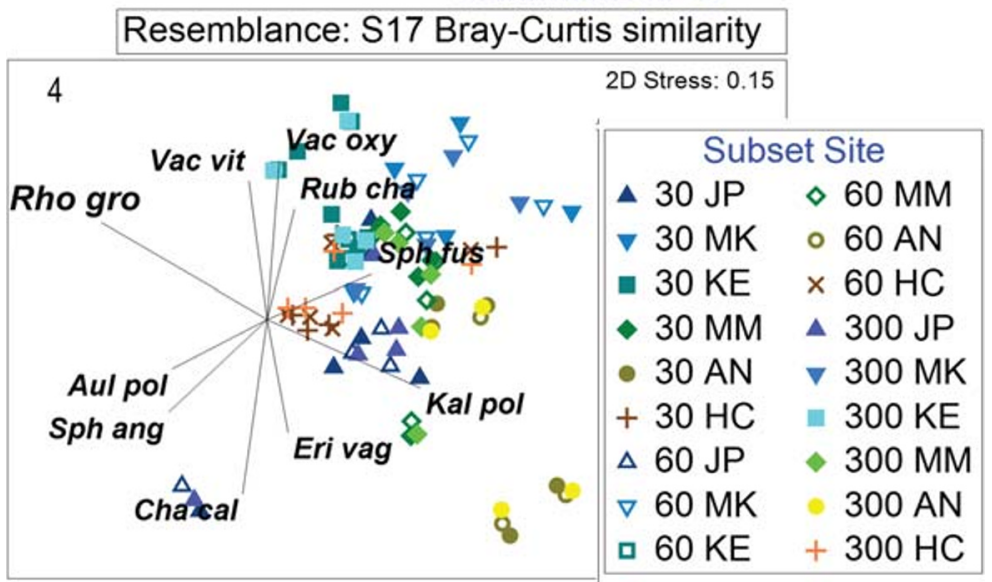


Fig. 5 Mean ( \pm S.E.) chlorophyll (chlorophyll $a$ and $b$ ) for 2018 and 2019. Different letters indicate significantly different values ( $p<0.05$ Tukey's test). $M c M=$ McMurray

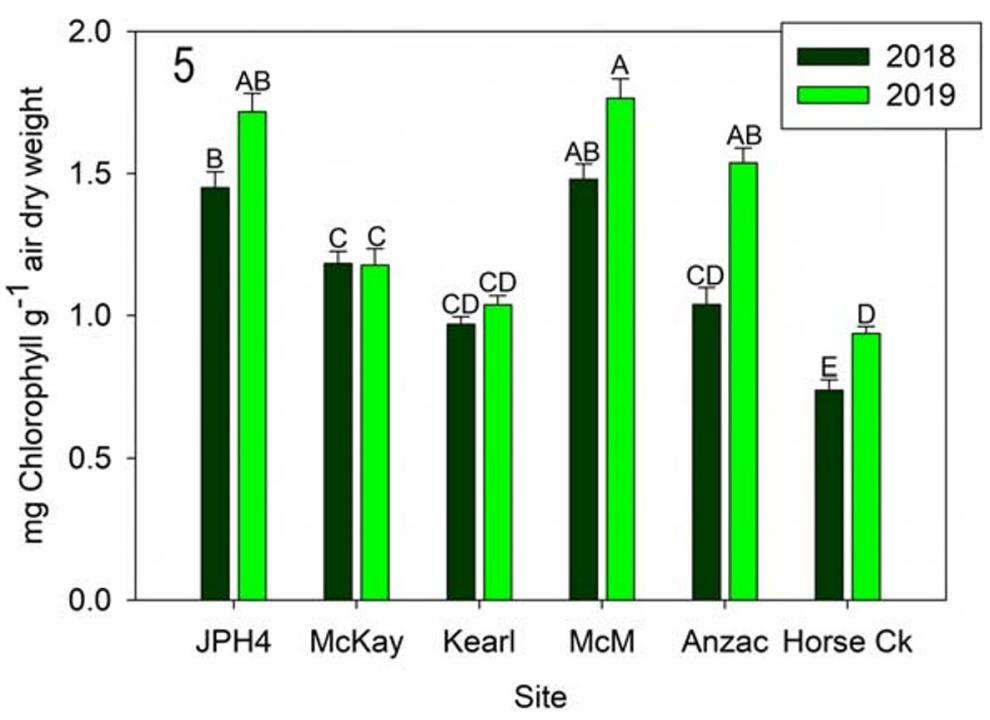

MPS lower in 2019 than 2018 at JPH4 and higher in 2019 than 2018 at Kearl (Fig. 9).

Aboveground net primary production of $R$. groenlandicum varied from 25 to $68 \mathrm{~g} \mathrm{~m}^{-2}$ year $^{-1}$, with one outlier (Kearl 2019) at $115 \mathrm{~g} \mathrm{~m}^{-2}$ year $^{-1}$ and differed between sites $(F=12.649, p<0.0001)$ and between years $(F=7.022, p=0.011)$, with an interaction between site and year $(F=17.722, p<0.0001)$ (Fig. 10). Both site and year differences were driven by the high 2019 value at Kearl; otherwise, individual sites were not different, and only Kearl differed between years.

\section{Chamaedaphne calyculata MPS and ANPP}

Similar to Rhododendron groenlandicum, slopes for modeled allometric growth equations (combined MPS vs. MPS for individual sites) for $C$. calyculata were not different for 2019 (ANCOVA, $F=0.91, p=0.476$ ). A comparison of modeled $C$. calyculata MPS and actual dry weight for 2019 , site $(F=3.957, p=0.009)$, mass type $(F=0.011, p=0.917)$, and the interaction between site and mass $(F=0.204, p=0.936)$ were not different. In particular, there were no differences between
Fig. 6 Mean ( \pm S.E.) percent of phaeophytin $a$ for 2018 and 2019. Different letters indicate significantly different values $(p<$ 0.05 Tukey's test). $M c M=$ McMurray

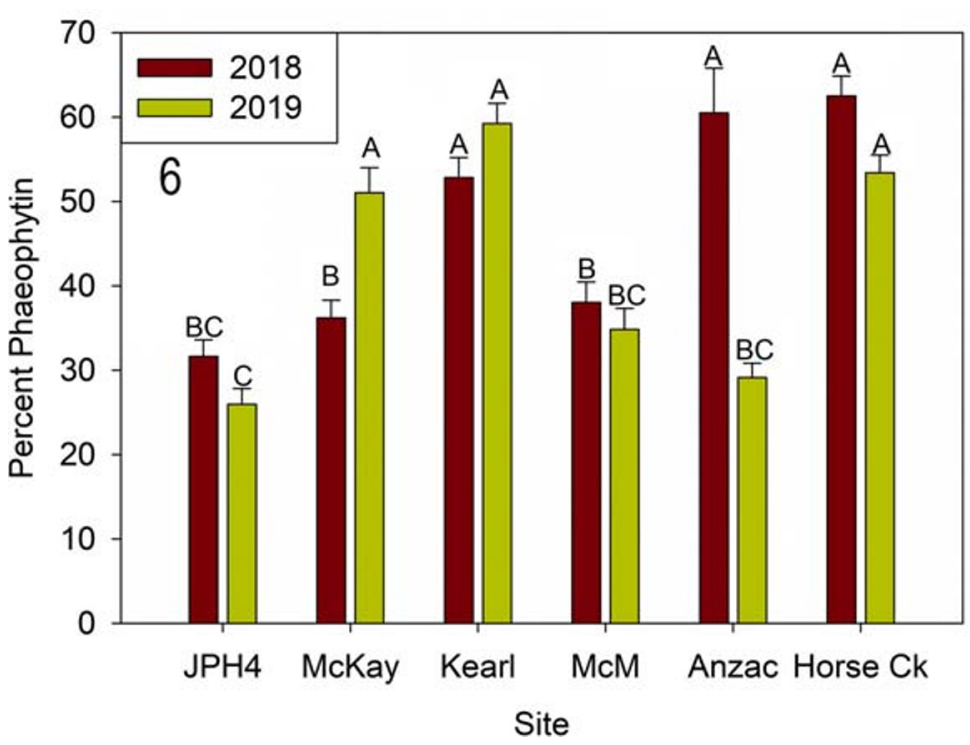


Fig. 7 Mean $( \pm$ S.E. $)$ ratio of OD 433 to $415 \mathrm{~nm}$ (chlorophyll $a$ to phaeophytin $a$ ) for 2018 and 2019. Different letters indicate significantly different values $(<$ 0.05 Tukey's test). $M c M=$ McMurray

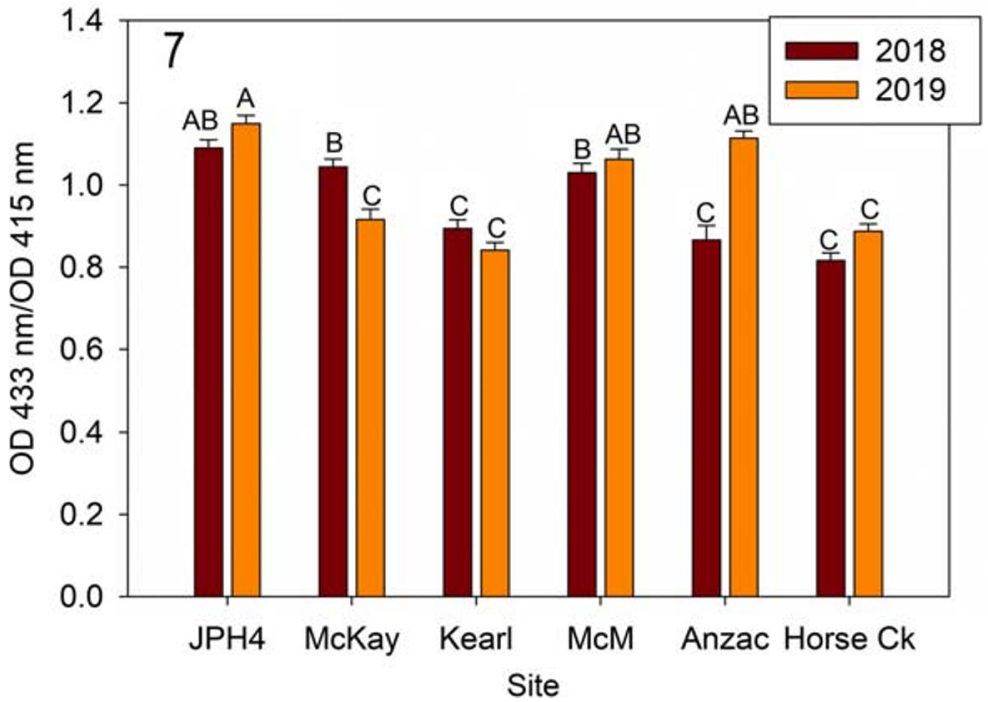

predicted MPS and dry weight for any of the five sites (C. calyculata absent at Kearl) (Fig. 11).

Overall, $C$. calyculata predicted MPS was greater in 2018 compared with 2019 ( $F=65.654, p<0.0001$, also different were site $(F=3.957, p=0.009)$, with an interaction between site and year $(F=3.885, p=0.018)$. On average, $C$. calyculata MPS was two times higher in $2018\left(\right.$ mean $=0.116 \mathrm{~g} \mathrm{segment}^{-1}$ year $\left.^{-1}\right)$ than 2019 $\left(\right.$ mean $=0.058 \mathrm{~g} \mathrm{segment}^{-1}$ year $\left.^{-1}\right)$. Specifically, MPS was higher in 2018 than 2019 at JPH4, McKay, and McMurray (Fig. 12). In 2019, there were no differences between the five sites, whereas in 2018 only Horse Creek differed from JPH4 and McKay.

Chamaedaphne calyculata NPP ranged from 3 to $24 \mathrm{~g} \mathrm{~m}^{-2}$ year $^{-1}$. Both site $(F=2.932, p=0.041)$ and year $(F=33.185, p<0.0001)$ were different, and the interaction between site and year $(F=3.408, p=$ $0.024)$ was significant. As with MPS, NPP was 2.1 times higher-on average-in 2018 (mean = $\left.15.73 \mathrm{~g} \mathrm{~m}^{-2} \mathrm{year}^{-1}\right)$ than $2019($ mean $=$ $7.37 \mathrm{~g} \mathrm{~m}^{-2}$ year $^{-1}$ ); however, among the five sites, only JPH4 and McMurray were different between years.
Fig. 8 Mean ( \pm S.E.)

Rhododendron groenlandicum measured dry weight and predicted mass per new growth segment (MPS). Different letters indicate significantly different values $(p<0.05$ Tukey's test). $M c M=$ McMurray

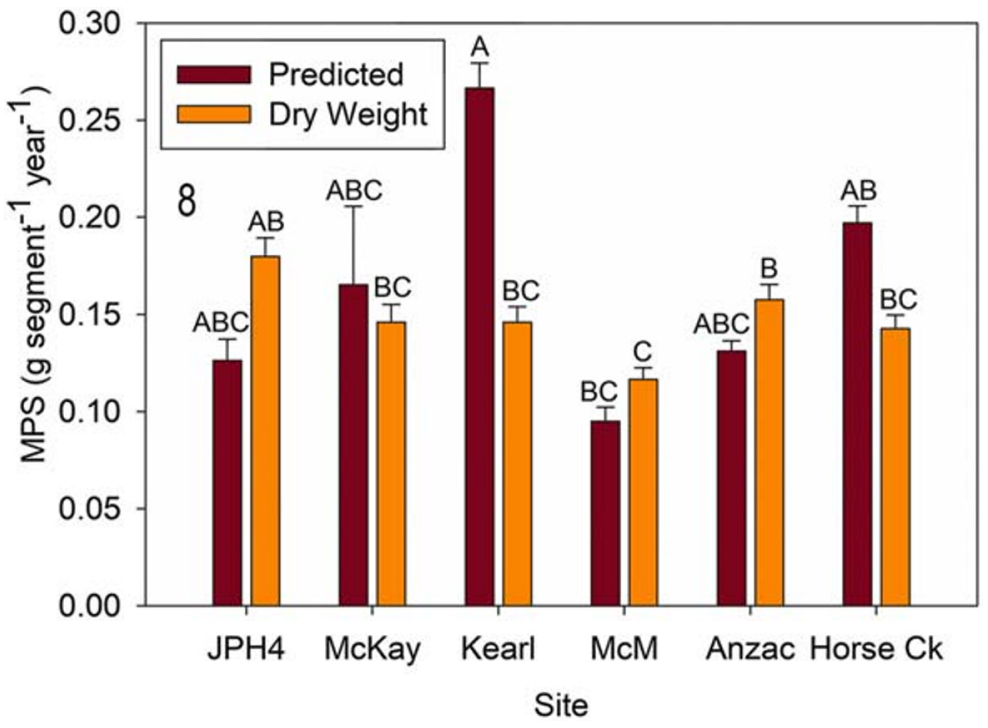


Fig. 9 Mean ( \pm S.E.)

Rhododendron groenlandicum mass per new growth segment (MPS) for 2018 and 2019.

Different letters indicate

significantly different values $(p<$

0.05 Tukey's test). $M c M=$

McMurray

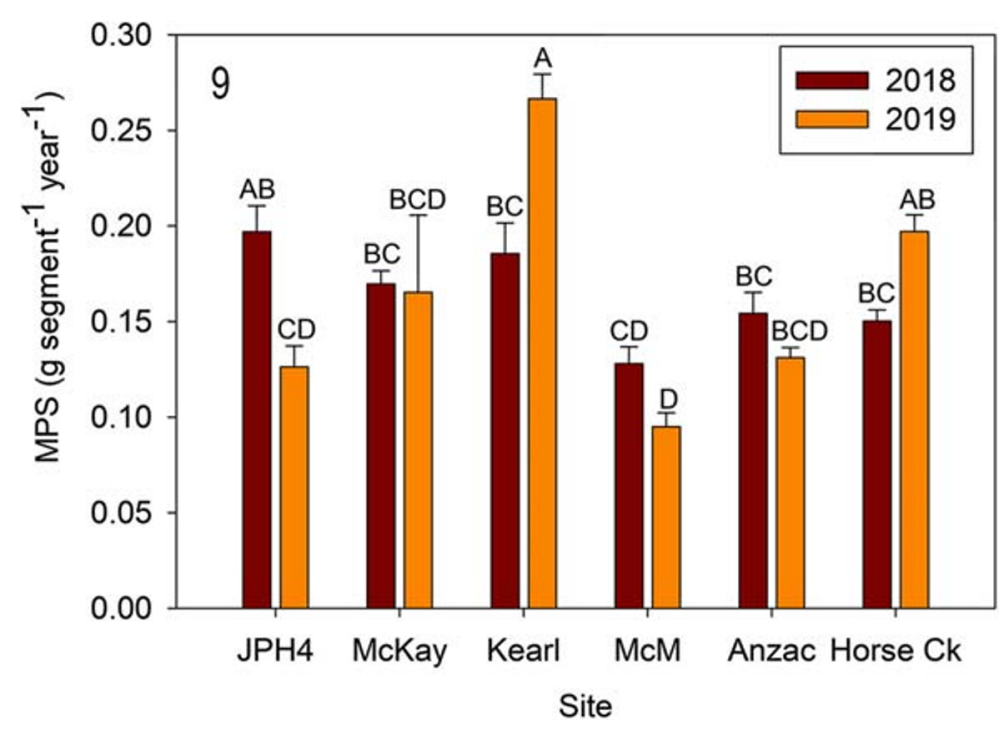

differences between sites $(p=0.002)$, and a nonsignificant year by site interaction $(p=0.057)$ (Table 4$)$. Stem mass density was higher at Anzac than at JPH4 or McKay (Table 5).

Linear growth was more variable resulting in strong site differences. Linear growth ranged from 0.69 to $2.36 \mathrm{~cm}$ year $^{-1}$ and exhibited a significant year by site interaction $(p<0.0001)$. Linear growth was highest at JPH4 in 2018 and lowest at Horse Creek in 2018 (Table 6). Annual NPP of S. fuscum ranged from 93.8 to $380.3 \mathrm{~g} \mathrm{~m}^{-2}$ year ${ }^{-1}$ (Table 6), with a significant year by site interaction $(p<0.0001)$. At Kearl, Anzac, and Horse Creek, NPP was lower in 2018 than in 2019, with
Fig. 10 Mean ( \pm S.E.)

Rhododendron groenlandicum net primary production (NPP) for 2018 and 2019. Different letters indicate significantly different values ( $\mathrm{p}<0.05$ Tukey's test). $M c M=$ McMurray, Plant

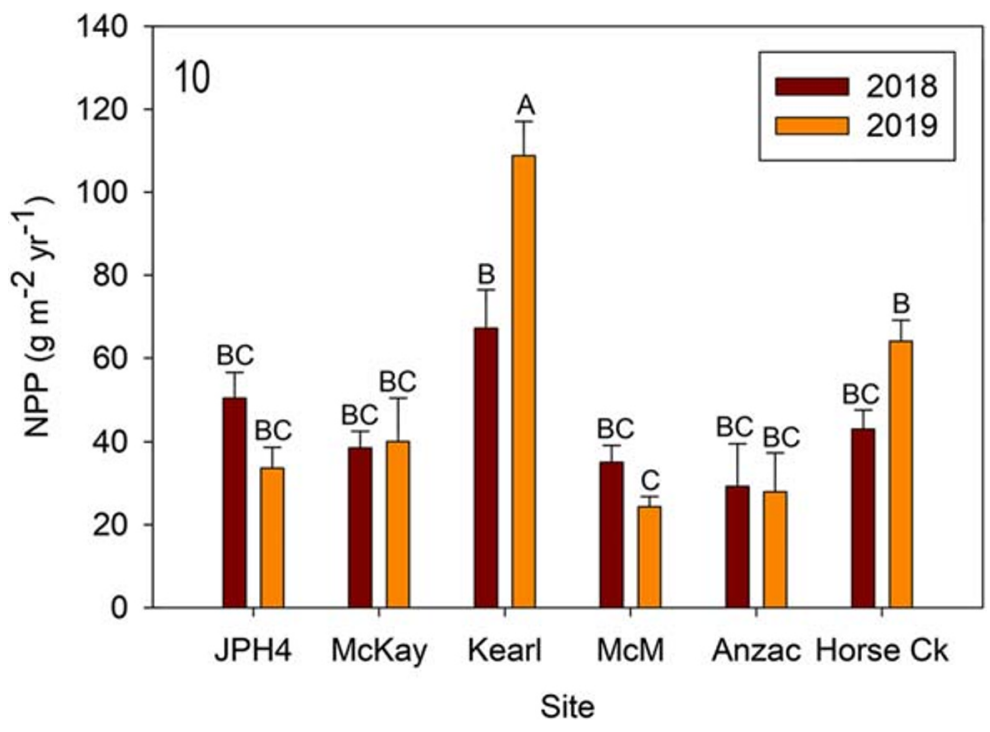


Fig. 11 Mean $( \pm$ S.E.

Chamaedaphne calyculata measured dry weight and predicted mass per new growth

Different letters indicate significantly different values $(p<$ 0.05 Tukey's test). $M c M=$ McMurray segment (MPS) for 2019.

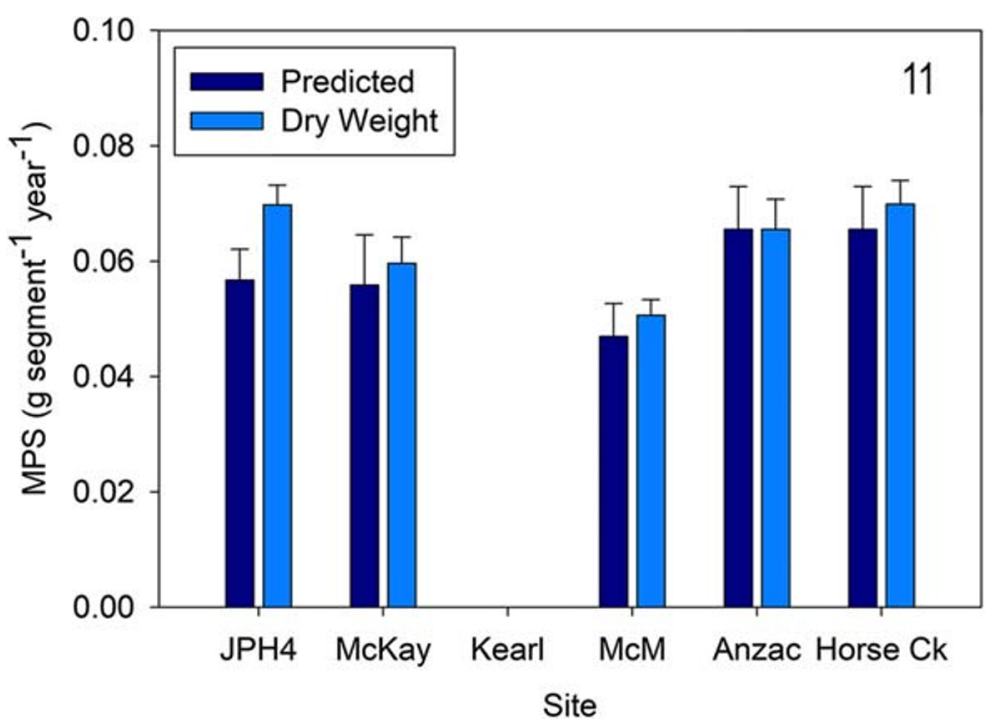

no difference between the 2 years at the other sites (Table 7).

Picea mariana leader length

Picea mariana leader lengths were significantly different between sites for the 1 year of measurement $(F=$ 12.302, $p<0.001)$. Picea mariana individuals at Horse Creek had the shortest leader lengths compared with all other sites. The second shortest leader lengths were found at McKay, with no differences between McKay, Kearl, and McMurray. Although not significantly different from trees at Anzac, trees at JPH4 had the longest leader lengths. Leader lengths at Anzac, Kearl, and McMurray were not different from one another (Online resource 2).

$\mathrm{N}$ and $\mathrm{S}$ deposition in 2018-2019

Over the past 20 years, gaseous emissions from oil sands operations have deposited $\mathrm{NH}_{4}{ }^{+}, \mathrm{NO}_{3}{ }^{-}$, and $\mathrm{SO}_{4}{ }^{2}$ on the surrounding landscape. Over this time period, $\mathrm{N}$ emissions have gradually increased, while since $2009 \mathrm{~S}$ emissions have declined to about half. Background deposition of $\mathrm{N}$ has been reported as $0.6 \mathrm{~kg} \mathrm{ha}^{-1}$ year $^{-1}$ and $0.4 \mathrm{~kg} \mathrm{ha}^{-1}$ year $^{-1}$ for sulfur (S) (Wieder et al.
Fig. 12 Mean $( \pm$ S.E.) Chamaedaphne calyculata measured dry weight and predicted mass per new growth segment (MPS) for 2019.

Different letters indicate significantly different values $(p<$ 0.05 Tukey's test). $M c M=$ McMurray




Fig. 13 Mean $( \pm$ S.E. $)$ Chamaedaphne calyculata net primary production (NPP) for 2018 and 2019. Different letters indicate significantly different values ( $p<0.05$ Tukey's test). $M c M=$ McMurray

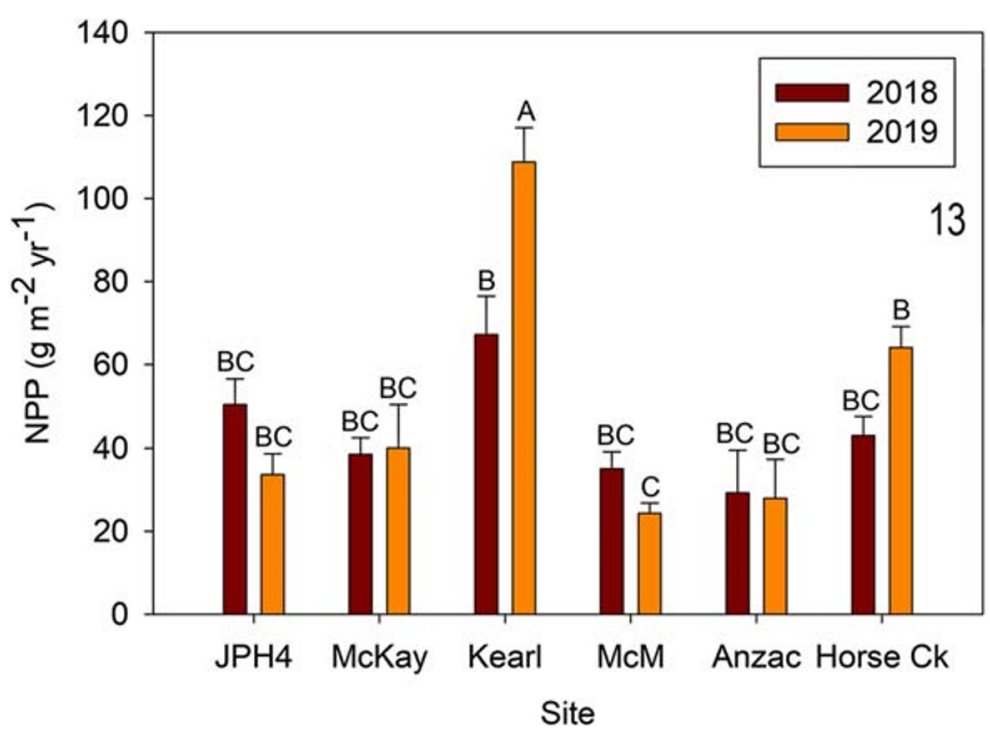

2016a). During the 2-year time period related to this study (October 2017 to October 2019), N deposition averaged $1.31 \mathrm{~kg} \mathrm{ha}^{-1}$ year ${ }^{-1}$ with $\mathrm{NO}_{3}{ }^{-}-\mathrm{N} 44 \%$ of the total. At our six sites annual deposition of $\mathrm{NH}_{4}{ }^{+}-\mathrm{N}$ varied from 0.52 to $0.96 \mathrm{~kg} \mathrm{ha}^{-1}$ year ${ }^{-1}, \mathrm{NO}_{3}{ }^{-} \mathrm{N}$ from 0.27 to $0.69 \mathrm{~kg} \mathrm{ha}^{-1}$ year $^{-1}$ with DIN varying from 0.82 to $1.51 \mathrm{~kg} \mathrm{ha}^{-1}$ year $^{-1}$. Sulfur deposition averaged $3.20 \mathrm{~kg} \mathrm{ha}^{-1}$ year $^{-1}$ and varied from 1.33 to $4.80 \mathrm{~kg} \mathrm{ha}^{-1}$ year $^{-1}$ (unpublished data). Between Oct. 15, 2018, and May 15, 2019, 49\% of the $\mathrm{N}$ deposition and $32 \%$ of the S deposition fell during the nongrowing season.

Table 4 Sphagnum fuscum plant density $\left(\# \mathrm{~cm}^{-2}\right)$. Values are means \pm standard errors ( $n=5$ for each year by site combination). Year or site means with the same letter do not differ significantly (ANOVA with a posteriori Tukey's HSD mean comparisons, $p=$ $0.05)$

\begin{tabular}{llll}
\hline Site & 2018 & 2019 & $\begin{array}{l}\text { Average across } \\
\text { all years }\end{array}$ \\
\hline JPH4 & $3.7 \pm 0.2$ & $3.1 \pm 0.1$ & $3.4 \pm 0.1 \mathrm{c}$ \\
Kearl & $3.5 \pm 0.3$ & $4.0 \pm 0.3$ & $3.8 \pm 0.2 \mathrm{bc}$ \\
McKay & $3.8 \pm 0.5$ & $3.9 \pm 0.3$ & $3.9 \pm 0.3 \mathrm{bc}$ \\
McMurray & $3.8 \pm 0.3$ & $3.9 \pm 0.5$ & $3.9 \pm 0.2 \mathrm{bc}$ \\
Anzac & $4.5 \pm 0.3$ & $6.5 \pm 0.9$ & $5.4 \pm 0.5 \mathrm{a}$ \\
Horse Creek & $5.1 \pm 0.6$ & $4.6 \pm 0.5$ & $4.8 \pm 0.4 \mathrm{ab}$ \\
Average across & $4.1 \pm 0.2 \mathrm{a}$ & $4.3 \pm 0.2 \mathrm{a}$ & \\
$\quad$ all sites & & & \\
\hline
\end{tabular}

Site variability related to $\mathrm{N}$ and $\mathrm{S}$ deposition

Among shrub attributes, Rhododendron groenlandicum abundance $\left(r^{2}=0.51\right)$ decreased with increases in $\mathrm{NH}_{4}{ }^{+} \mathrm{N}$ and DIN deposition $\left(r^{2}=0.36\right.$; Fig. 15). Associated with these decreases in abundance was a decrease in NPP as DIN increased $\left(r^{2}=0.43\right)$; however, mass per segment showed no change (Fig. 14). Chamaedaphne calyculata abundance increased with an increase in $\mathrm{NO}_{3}{ }^{-} \mathrm{N}$ deposition $\left(r^{2}=0.54\right)$ as well as mass per segment $\left(r^{2}=0.39\right)$ and NPP $\left(r^{2}=0.58\right.$; Fig. 13). Evernia mesomorpha chlorophyll concentration increased with increases in $\mathrm{NO}_{3}{ }^{-} \mathrm{N}$ deposition $\left(r^{2}=0.51\right)$ and DIN $\left(r^{2}=0.47\right)$, along with a decrease in phaeophytin $\left(r^{2}=0.35\right)$ (and chlorophyll/phaeophytin ratio $r^{2}=0.63$; Fig. 14). Sphagnum plant density $\left(r^{2}=0.76\right)$ and stem mass density $\left(r^{2}=0.48\right.$, the latter dependent of the former (cf. Wieder et al. 2016a, b) increased as distance from the upgrader stacks increased, while linear growth increased in association with increases in $\mathrm{NO}_{3}{ }^{-} \mathrm{N}$ deposition $\left(r^{2}=\right.$ 0.58); however, Sphagnum NPP was not affected (Fig. 15). $\mathrm{NO}_{3}{ }^{-} \mathrm{N}$ deposition was related to plant/lichen responses more than any other deposition-related factor (7 of the 14 significant responses), with six of the seven positive and the remaining negative phaeophytin one related to the positive chlorophyll increase in Evernia (Table 8).

\section{Discussion}

Both plant community structure and function are attributes of equal importance in assessing the health of 
Table 5 Sphagnum fuscum stem mass density $\left(\mathrm{mg} \mathrm{cm}^{-3}\right)$. Values are means \pm standard errors ( $n=5$ for each year by site combination). Year or site means with the same letter do not differ significantly (ANOVA with a posteriori Tukey's HSD mean comparisons, $p=0.05$ )

\begin{tabular}{lccc}
\hline Site & 2018 & 2019 & Average across all years \\
\hline JPH4 & $7.4 \pm 0.6$ & $9.5 \pm 1.1$ & $8.4 \pm 0.7 \mathrm{~b}$ \\
Kearl & $7.6 \pm 1.4$ & $14.5 \pm 1.5$ & $11.0 \pm 1.5 \mathrm{ab}$ \\
McKay & $7.9 \pm 1.5$ & $9.3 \pm 1.2$ & $8.6 \pm 0.9 \mathrm{~b}$ \\
McMurray & $11.5 \pm 1.2$ & $9.4 \pm 1.1$ & $12.8 \pm 1.1 \mathrm{ab}$ \\
Anzac & $11.5 \pm 1.7$ & $18.6 \pm 0.7$ & $14.6 \pm 2.4 \mathrm{a}$ \\
Horse Creek & $14.0 \pm 3.1$ & $13.7 \pm 2.0$ & $13.9 \pm 1.7 \mathrm{ab}$ \\
Average across all sites & $10.0 \pm 0.8 \mathrm{~b}$ & $12.7 \pm 1.0 \mathrm{a}$ & \\
\hline
\end{tabular}

ecosystems. Plant community structure can be examined through assessment of plant species abundances that can serve as indicators of environmental changes occurring at the site level. Functional attributes that include growth and net primary production also are means of assessing how environmental changes affect the overall health of the ecosystem long before changes are evident in tissue concentrations. Accurate monitoring protocols are essential for these assessments as are baseline data that reflect natural annual variation.

In $\mathrm{N}$-limited habitats increasing $\mathrm{N}$ deposition could lead to, first, stimulation of growth and increased NPP, and secondly, when $\mathrm{N}$ availability exceeds demands of growth, to increases in tissue $\mathrm{N}$-concentrations. Over the past several decades, considerable research has examined either growth or tissue concentration responses to experimentally applied $\mathrm{N}$ and $\mathrm{S}$, including studies in Europe (reviewed by Bobbink and Hettelingh 2011)

Table 6 Sphagnum fuscum linear growth $\left(\mathrm{cm} \mathrm{year}^{-1}\right)$, assuming a 140 -day growing season. Values are means \pm standard errors $(n=$ 5 for each year by site combination). Year or site means with the same letter do not differ significantly (nested ANOVA with a posteriori Tukey's HSD mean comparisons, $p=0.05$ )

\begin{tabular}{llll}
\hline Site & 2018 & 2019 & $\begin{array}{l}\text { Average across } \\
\text { all years }\end{array}$ \\
\hline JPH4 & $2.36 \pm 0.21 \mathrm{a}$ & $1.92 \pm 0.49 \mathrm{~b}$ & $2.14 \pm 0.14$ \\
Kearl & $1.24 \pm 0.30 \mathrm{ef}$ & $1.08 \pm 0.25 \mathrm{f}$ & $1.16 \pm 0.09$ \\
McKay & $1.47 \pm 0.42 \mathrm{c}-\mathrm{e}$ & $1.31 \pm 0.20 \mathrm{~d}-\mathrm{f}$ & $1.39 \pm 0.10$ \\
McMurray & $1.43 \pm 0.12 \mathrm{de}$ & $1.70 \pm 0.19 \mathrm{bc}$ & $1.56 \pm 0.07$ \\
Anzac & $1.51 \pm 0.26 \mathrm{~cd}$ & $1.91 \pm 0.18 \mathrm{~b}$ & $1.71 \pm 0.09$ \\
$\begin{array}{l}\text { Horse Creek } \\
\text { Average }\end{array}$ & $0.69 \pm 0.14 \mathrm{~g}$ & $1.46 \pm 0.23 \mathrm{de}$ & $1.08 \pm 0.14$ \\
$\begin{array}{l}\text { across all } \\
\text { sites }\end{array}$ & $1.45 \pm 0.10$ & $1.56 \pm 0.07$ & \\
\hline
\end{tabular}

and eastern North America (e.g., Bubier et al. 2011; Juutinen et al. 2015). Nearly all of these studies were done in regions having historically high $\mathrm{N}$ deposition and in bogs that have quite different flora than in Alberta, making comparisons difficult. Bogs in continental North America (west of central Ontario to the Canadian Rocky Mountains) are unique in being dominated by the tree species, Picea mariana, and the tall shrub, Rhododendron groenlandicum, both species endemic to North America. Whereas western boreal bogs have an open canopy of $P$. mariana (Wieder et al. 2009), bogs of eastern North America either have no trees or only small scattered individuals of the species (Glaser and Janssens 1986). Bogs of Eurasia are either treeless or have scattered individuals of Pinus sylvestris and hummocks of Calluna vulgaris (Ruuhijärvi 1983; Sjörs 1983), both species that do not occur naturally in North America. These floristic differences may be important to recog-

Table 7 Sphagnum fuscum NPP $\left(\mathrm{g} \mathrm{m}^{-2}\right.$ year $\left.^{-1}\right)$, assuming a 140day growing season. Values are means \pm standard errors $(n=5$ for each year by site combination). Year by site means with the same letter do not differ significantly (nested ANOVA with a posteriori Tukey's HSD mean comparisons, $p=0.05$ )

\begin{tabular}{|c|c|c|c|}
\hline Site & 2018 & 2019 & $\begin{array}{l}\text { Average } \\
\text { across all years }\end{array}$ \\
\hline JPH4 & $173.3 \pm 15.6 c$ & $182.2 \pm 46.9 \mathrm{bc}$ & $177.7 \pm 10.5$ \\
\hline Kearl & $93.8 \pm 22.7 f$ & $156.7 \pm 36.0 \mathrm{~cd}$ & $125.2 \pm 13.8$ \\
\hline McKay & $117.0 \pm 33.2 \mathrm{ef}$ & $132.4 \pm 20.7 \mathrm{de}$ & $124.7 \pm 8.6$ \\
\hline McMurray & $164.0 \pm 14.3 \mathrm{c}$ & $159.5 \pm 18.1 \mathrm{c}$ & $161.8 \pm 4.9$ \\
\hline Anzac & $173.2 \pm 30.2 \mathrm{c}$ & $375.8 \pm 34.9 \mathrm{a}$ & $274.5 \pm 35.1$ \\
\hline Horse Creek & $96.8 \pm 19.0 \mathrm{f}$ & $200.3 \pm 30.9 b$ & $148.5 \pm 18.9$ \\
\hline $\begin{array}{l}\text { Average } \\
\text { across all } \\
\text { sites }\end{array}$ & $136.3 \pm 7.5$ & $201.1 \pm 16.9$ & \\
\hline
\end{tabular}





Distance $(k m) \mathrm{NH}_{4}{ }^{+}-\mathrm{N}\left(\mu \mathrm{g} \mathrm{m}^{-2} \mathrm{~d}^{-1}\right) \mathrm{NO}_{3}{ }^{-}-\mathrm{N}\left(\mu \mathrm{g} \mathrm{m}^{-2} \mathrm{~d}^{-1}\right) \mathrm{DIN}\left(\mu \mathrm{g} \mathrm{m}^{-2} \mathrm{~d}^{-1}\right) \mathrm{SO}_{4}{ }^{2-}-\mathrm{S}\left(\mu \mathrm{g} \mathrm{m}^{-2} \mathrm{~d}^{-1}\right)$

Fig. 14 Plant/lichen responses for mass per segment (MPS) and net primary production (NPP) for Rhododendron groenlandicum (Rhodo) and Chamaedaphne calyculata (Cham), and chlorophyll, phaeophytin and the ratio of chlorophyll to phaeophytin for
Evernia mesomorpha as a function of growing season $\mathrm{N}$ and $\mathrm{S}$ deposition for 20182019 at six research sites. Significant linear regressions shown 

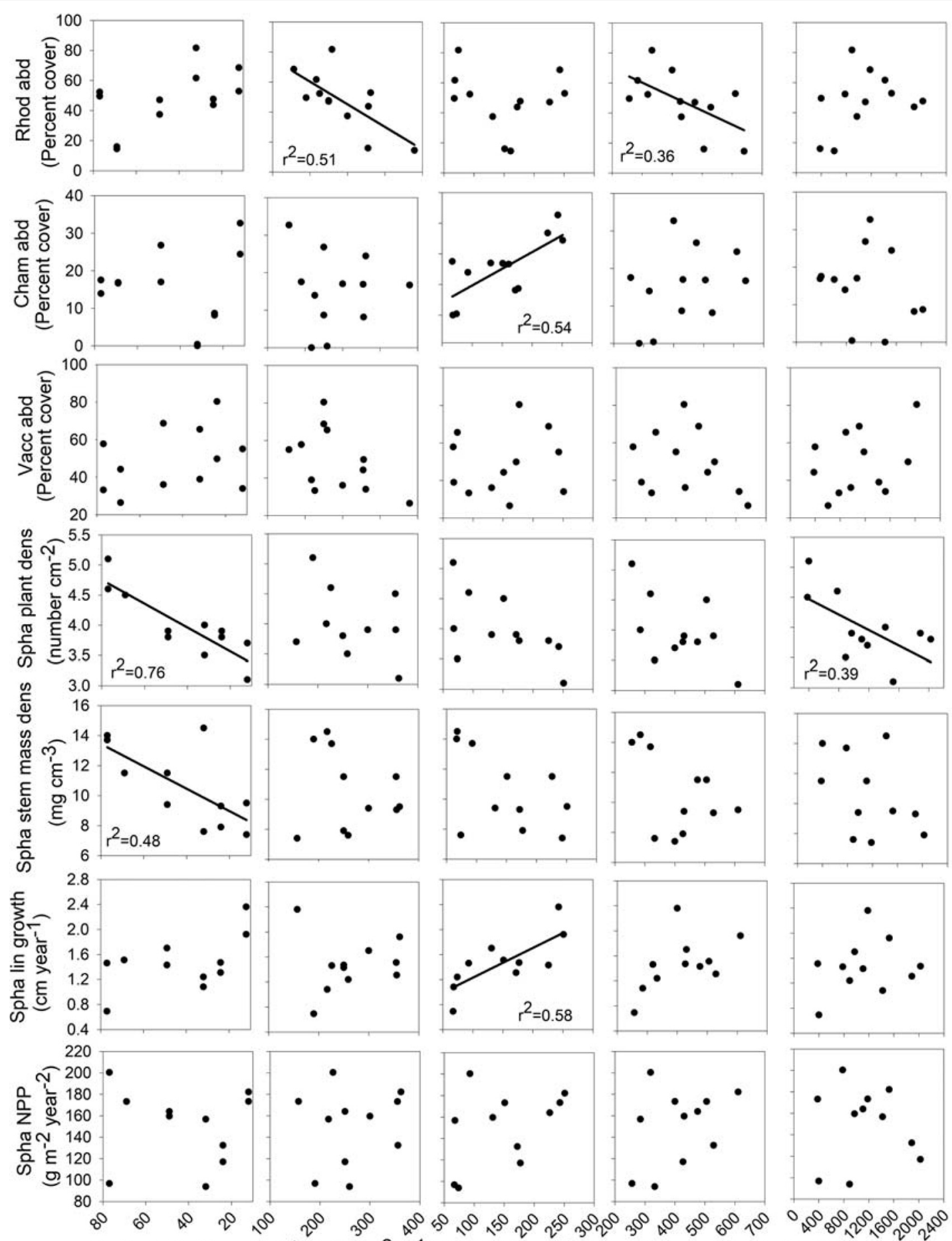

Distance $(\mathrm{km}) \quad \mathrm{NH}_{4}^{+}-\mathrm{N}\left(\mu \mathrm{g} \mathrm{m}^{-2} \mathrm{~d}^{-1}\right) \mathrm{NO}_{3}^{-}-\mathrm{N}\left(\mu \mathrm{g} \mathrm{m}^{-2} \mathrm{~d}^{-1}\right)$ DIN $\left(\mu \mathrm{g} \mathrm{m}^{-2} \mathrm{~d}^{-1}\right) \mathrm{SO}_{4}{ }^{2-}-\mathrm{S}\left(\mu \mathrm{g} \mathrm{m}^{-2} \mathrm{~d}^{-1}\right)$

Fig. 15 Plant/lichen responses for abundance (abd) for Rhododendron groenlandicum (Rhod), Chamaedaphne calyculata (Cham), and Vaccinium oxycoccos (Vacc), and plant density, stem mass density, linear growth, and NPP for Sphagnum fuscum
(Spha) as a function of growing season $\mathrm{N}$ and $\mathrm{S}$ deposition for 20182019 at six research sites. Significant linear regressions shown 


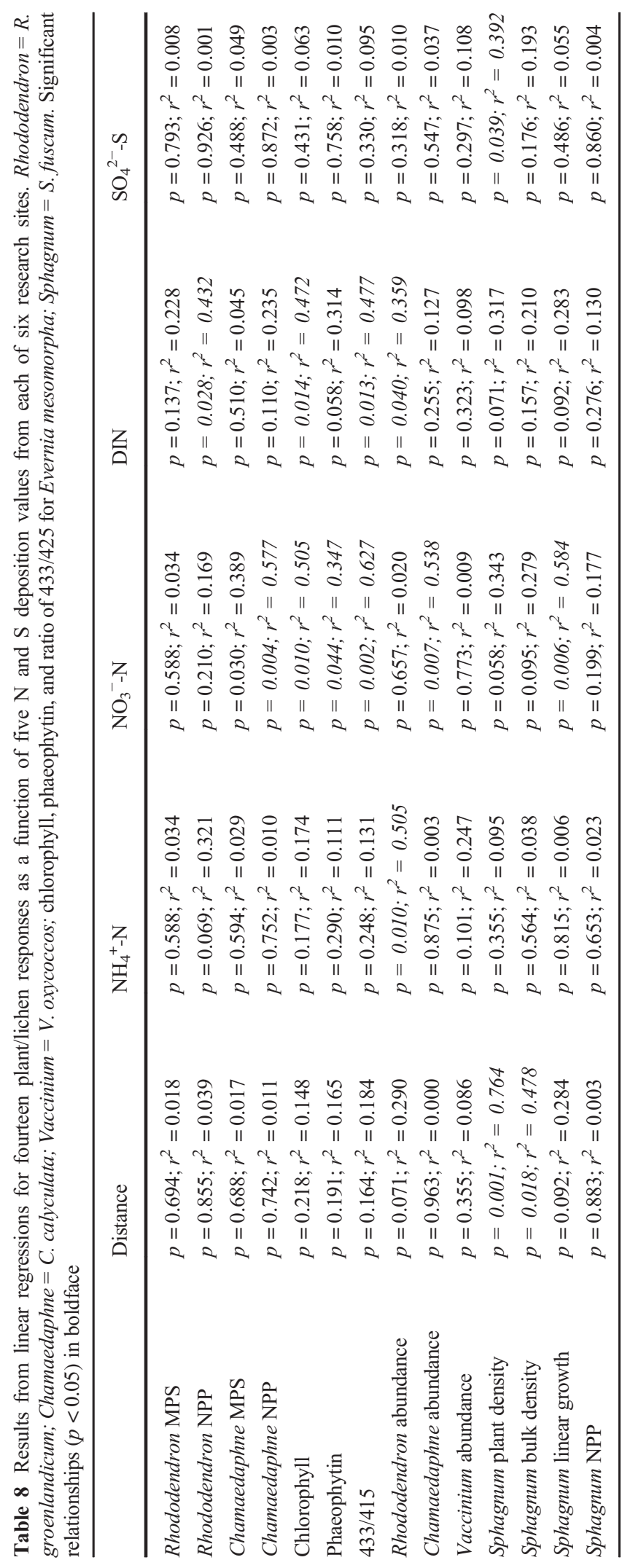


nize in any long-term evaluation of plant responses to $\mathrm{N}$ deposition.

Our objective was to develop a protocol that can be used to quantify important attributes of bog structure and function. Recent experimental studies by Wieder et al. (2019) explored how a bog ecosystem was affected by increasing levels of $\mathrm{N}$ deposition, and that study has provided the framework from which we chose appropriate attributes to include in a monitoring protocol. We tested our protocol by examining plant community structure using a line transect and compared the results to a more limited point transect method. We developed a non-destructive field-based method for assessing plant annual growth and production utilizing the dominant shrubs present at each site. We used an epiphytic lichen species to develop a suitable technique for using lichen chlorophyll/phaeophytin ratios as an indicator of lichen health, and examined the variability in Sphagnum fuscum growth and NPP. We used leader length of Picea mariana to examine variability in tree growth.

Plant community composition (Figs. 1, 2, 3, and 4): Ombrotrophic bogs are among the most species poor plant communities in the boreal region (Vitt 2006). Even though we recorded only 22 species, our six sites differed in individual species abundances. The sites differed largely owing to variability in shrub abundances, with high consistency of individual plots with each site Over the 2 years of measurement, the six sites differed between years, with shrub cover greater (by 1.23 times) in 2018 compared with 2019. Average daily temperatures in 2018 were approximately $10 \%$ higher than in 2019 for the growing season up to July 1 (data from weather station at the Anzac site, not shown). The significant plant community change between years was related to lower, but variable vascular plant cover in 2019, varying from 17 to $34 \%$ lower overall cover. Especially noteworthy was the large decrease in Vaccinium oxycoccos frequency (51\% lower in 2019). Other species also contributed to the decrease in abundance ranging from 4 to $16 \%$ lower; however, these lower abundances in 2018 were not consistent between sites. For example, the dominant species, Rhododendron groenlandicum, was higher at two sites, but only slightly higher at three sites and slightly lower at one site; however, the overall effect of this variation was a $17 \%$ increase in $R$. groenlandicum abundance when all sites are considered together. We determined that our 2year line transect data were sufficiently sensitive to show that bog communities vary, both between sites and over time. We suggest that a line transect method has appropriate sensitivity for assessing changes in bog plant communities, but that site variability must be taken into account in future monitoring by assessing changes at individual sites over a temporal frame.

Data collection in the field for line transects is timeconsuming and rather tedious. We analyzed our transect data to determine if we could reduce the effort in the field by reducing the line transect data to points along the line transect. Surprisingly, point observation methods yielded no differences from the line transect and provide ordinations that position plots from point and line transects in close proximity to one another for both 2018 and 2019 (Fig. 4). We suggest that the similarity of these methods indicate that at the hummockscale in bogs, individual species occurrences are quite consistent along the hummock surface and that when field effort is a concern, the point-intercept method may provide sufficient data.

Lichen chlorophyll and phaeophytin (Figs. 5, 6, and 7): Chlorophyll $a / b$ concentrations were variable, differing some two-fold (ca. 0.7 to $1.7 \mathrm{mg} \mathrm{g}^{-1}$ chlorophyll) and in general, formed two groups: Anzac-2019, JPH4, and McMurray in one group with relatively high chlorophyll concentrations, while Anzac-2018, Horse Creek, Kearl, and McKay had low concentrations. Three of the six sites had significant differences between years. Likewise, phaeophytin varied from ca. $30 \%$ to over $60 \%$ between sites with two mostly similar groups and year differences as those of chlorophyll $a / b$ concentrations. Groups and years with high chlorophyll content had low phaeophytin concentrations. The ratios of chlorophyll to phaeophytin were less variable, but overall showed the same patterns.

Rhododendron growth and ANPP (Figs. 8, 9, and 10): Actual mass per new growth segment (MPS - as a surrogate for new growth) was measured destructively in 2019 and varied from 0.12 to $0.18 \mathrm{~g} \mathrm{segment}^{-1}$ for the six sites. Two sites with high MPS (Anzac [0.16] and JPH4 [0.18]) differed from McMurray (0.12) with a low value. We produced algorithms for MPS for the six individual sites and an algorithm for all sites combined. Slopes for individual site algorithms were not different values from the overall one; thus, one generalized algorithm appears to be sufficient for all of our sites $\left(r^{2}=\right.$ 0.85 ), and probably useful for all bog sites in the region.

Except for Kearl, predicted 2019 MPS values were not different from actual values. Comparing the 2 years, predicted MPS revealed only JPH4 (lower in 2019) and 
Kearl (higher in 2019) had differing MPS values. The difference at JPH4 between 2018 and 2019 seems real as the variation is within that from other sites and although not significant, the abundance of Rhododendron at this site was also lower (Fig. 2). However, the large difference at Kearl is seemingly anomalous, as the abundance values were the reverse and the MPS for 2019 was much outside of the ranges of all the remaining sites. We attribute this high value to destructively sampled Rhododendron leaves and stems being smaller than those from plants within the quadrats. Our MPS values $(0.12$ to $0.18 \mathrm{~g} \mathrm{segment}^{-1}$ ) are somewhat higher than those reported by Wieder et al. (2019) (ca. 0.06-0.12) for Mariana Bog, a nearby site with less abundance of Rhododendron.

Comparing our six bog sites to the Mariana bog site used in Wieder et al. (2019) revealed differences in stem densities for Rhododendron. Stem densities varied from 174 (Anzac) to 355 (Kearl) stems $\mathrm{m}^{-2}$ in 2018 and from 205 (Anzac) to 409 (Kearl) stems $\mathrm{m}^{-2}$ in 2019. Five of the six sites had stem counts from 1 to 54 (Kearl) stems greater in 2019, with one site (McMurray slightly lower (-16), but overall stem counts did not differ in the 2 years. These stem densities are higher compared with those reported from (Wieder et al. 2019) with stem densities around 50 stems $\mathrm{m}^{-2}$. The lower stem densities reported in Wieder et al. (2019) yielded much lower NPP (ca. 2$15 \mathrm{~g} \mathrm{~m}^{-2}$ year $\left.^{-1}\right)$. Actual NPP from our six sites varied from $25 \mathrm{~g} \mathrm{~m}^{-2}$ year $^{-1}$ (McMurray 2019) to $70 \mathrm{~g} \mathrm{~m}^{-2}$ year $^{-1}$ (Kearl 2018) and $110 \mathrm{~g} \mathrm{~m}^{-2}$ year $^{-1}$ (Kearl 2019). Both MPS and stem density are key components of NPP for Rhododendron. Our predicted MPS plus stem density count predicted wide variation in NPP between sites, but little variation between years (only the anomalous Kearl 2019 reading was different between years), suggesting that like our line transect analysis, comparisons over time must be addressed for individual sites.

Chamaedaphne growth and ANPP (Figs. 11, 12, and 13). We used similar methods for MPS and NPP of C. calyculata, the shrub with moderate abundances at several of the sites (absent at Kearl). Our algorithm results are similar to those of Rhododendron $\left(r^{2}=\right.$ 0.91) with an overall algorithm sufficient to predict MPS for Chamaedaphne (our $r^{2}$ values are identical to those for these two species in Wieder et al. (2019)). Predicted mass growth in 2019 values was not different from actual measured ones and varied from 0.05 to $0.07 \mathrm{~g} \mathrm{segment}^{-1}$ for the five sites. Predicted values for 2018 were higher at three of the five sites (JPH4,
McKay, and McMurray) compared with those from 2019. NPP for Chamaedaphne were much lower than those for Rhododendron, varying from 2.5 (Horse Creek 2019) to $23 \mathrm{~g} \mathrm{~m}^{-2}$ year $^{-1}$ (JPH4 2018) and are comparable to those from Mariana Lake Bog (4 to $16 \mathrm{~g} \mathrm{~m}^{-2}$ year $^{-1}$; Wieder et al. 2019).

Sphagnum NPP (Tables 4, 5, 6, and 7): The ground layer of bogs is of fundamental importance to ecosystem function and the ground layer of mature bogs is dominated by species of Sphagnum (Belland and Vitt 1995). Large expansive hummocks have a continuous layer of S. fuscum, while wetter hollows can have areas dominated by $S$. angustifolium and $S$. magellanicum. In boreal Canada, a recent study demonstrated that while linear growth was not affected by increased $\mathrm{N}$ deposition, plant density and stem mass density were resulting in a decrease in NPP (Wieder et al. 2019). That study reported at Mariana Bog the NPP for control sites was $281 \mathrm{~g} \mathrm{~m}^{-2}$ year $^{-1}$, and linear growth $2.3 \mathrm{~cm}_{\text {year }}{ }^{-1}$ over the course of the 5-year study. Our study reported Sphagnum NPP that averaged 136.3 in 2018 and 201.0 in $2019 \mathrm{~g} \mathrm{~m}^{-2}$ year $^{-1}$ and ranged from 94 to $376 \mathrm{~g} \mathrm{~m}^{-2}$ year $^{-1}$, while linear growth averaged 1.45 in 2018 and 1.56 in $2019 \mathrm{~cm}$ year $^{-1}$ and ranged from 0.69 to $2.36 \mathrm{~cm} \mathrm{year}^{-1}$. Compared with the Mariana Bog, Sphagnum linear growth and NPP for our sites were lower. Thus, our sites had greater shrub abundances and shrub production and less ground layer growth and production. Sphagnum performance was more variable than that of Rhododendron and Chamaedaphne, with high variability among the sites in both linear growth and NPP. In general, NPP at the six sites separated into two groups in 2018 and into three groups in 2019; four of the sites were different between the 2 years, again indicating that monitoring must compare individual sites over time.

We examined leader lengths of Picea mariana by measuring the previous year's leader. Although sites were different, this difference was driven by two sites (Anzac and JPH4) having long leaders (>4 cm) vs. Horse Creek having short ones $(<2 \mathrm{~cm})$. We are unable to make a recommendation based on these limited data, and measurements in additional years are necessary.

The significant site variation in all of the plant and lichen attributes led us to consider whether some of this variation is related to differences in either $\mathrm{N}$ or $\mathrm{S}$ deposition. Background deposition for the oil sands region has been reported as $0.6 \mathrm{~kg} \mathrm{ha}^{-1}$ year $^{-1}$ for $\mathrm{N}$ and $0.4 \mathrm{~kg} \mathrm{ha}^{-1}$ year $^{-1}$ for $\mathrm{S}$, with our six sites varying from 
0.82 - to $1.51 \mathrm{~kg} \mathrm{ha}^{-1}$ year $^{-1}$ for $\mathrm{N}$ and 1.33 to $4.80 \mathrm{~kg} \mathrm{ha}^{-1}$ year $^{-1}$ for $\mathrm{S}$. These increases in $\mathrm{N}$, although 1.4 to 2.5 fold higher than regional background levels remain relatively low given that the critical load recommended by Wieder et al. (2019) of $3 \mathrm{~N} \mathrm{~kg} \mathrm{ha}^{-1}$ year $^{-1}$ and that of Pardo et al. (2011) of 4-6 $\mathrm{N} \mathrm{kg} \mathrm{ha}^{-1}$ year $^{-1}$ for epiphytic lichens of the Northern Forest Ecoregion. Significant decreases in Rhododendron abundance and NPP and increases in Chamaedaphne MPS and NPP provide evidence that the shrub component is sensitive to changes in $\mathrm{N}$ deposition. Likewise, increases in Evernia chlorophyll concentration coupled to a decrease in phaeophytin concentration are early indicators of depositional changes. Concentrations of chlorophyll and phaeophytin, along with their ratios, have been used extensively in the literature as indicators of physiological health of lichen thalli (Ronen and Galun 1984). Increased chlorophyll concentrations are an indication of an early fertilization response to increased $\mathrm{N}$ exposure, with increased chlorophyll allowing for increased photosynthesis and increased growth (Ra et al. 2005) and may be an early warning response to increased $\mathrm{N}$ deposition (Berryman et al. 2016; Johansson et al. 2010). However, long-term chronic exposure to atmospheric stressors such as $\mathrm{N}$ and $\mathrm{S}$ may lead to increased phaeophytin, an increase in tissue concentrations, and eventual death of the lichen thalli.

Responses to increases in S appear to be limited with only Sphagnum plant density affected; however, this response is strongly related to distance from the upgrader stacks. The decrease in Sphagnum plant density was coupled to an increase in linear growth resulting in no change in NPP. Based on these 2 years of data, of the 14 plant/lichen responses we monitored, variation in nine was significantly related to $\mathrm{N}$ deposition, only one related to $\mathrm{S}$ deposition, and two related to distance from the upgrader stacks (and one of these associated with $\mathrm{S}$ deposition). We found that between 35 and $76 \%$ of the variability present in these nine responses could be explained by $\mathrm{N}$ or $\mathrm{S}$ deposition.

\section{Conclusion}

Considerable research conducted across Europe has provided widespread agreement that increasing $\mathrm{N}$ deposition has negative consequences for bog structure and function (reviewed in Wieder et al. 2019), and these responses have been examined in North America (Bubier et al. 2007,
2011; Rochefort et al. 1990). In general, most important of these responses were changes in the ground layer and vascular plants. Especially noteworthy was the increase in abundance of vascular plants and decrease or change in the species of Sphagnum at higher N concentrations. Over the 2 years of our study we have assessed the responses of two shrubs, the epiphytic lichen Evernia mesomorpha and Sphagnum fuscum, to assess the responses in six boreal bogs in order to develop a protocol for monitoring future effects of changing atmospheric $\mathrm{N}$ and $\mathrm{S}$ deposition regimes. The ombrogenous condition of bog ecosystems provides a unique opportunity for these assessments; however, at present no structured protocol has been available. We conclude the following: (1) Bog communities are species poor with high degree of similarity for vascular plant occurrences; however, differences in bryophyte species and variation in vascular plant abundances (especially that of shrubs) indicate that bog sites are individually distinct, and monitoring over a temporal framework must take this site variation into account. (2) At the plot level, both line-intercept and point-intercept methods of assessing plant abundances provided similar results, with almost all plots within a site having high similarity and indicating that individual sites have highly uniform structure. (3) Sites also are variable between years especially in shrub abundances that couple to differences in annual growth and ANPP. Also, variable between years and sites is Sphagnum NPP. (4) We developed allometric growth equations for non-destructively predicting annual MPS and ANNP for two dominant shrubs. These equations predicted differences in annual NPP between years (higher in 2018 compared with 2019) and between many of the sites. (5) We found the lichen Evernia mesomorpha was abundant at all of the sites and easy to collect in the field. Laboratory analyses of chlorophyll and phaeophytin contents were straight-forward and yielded data that indicate clear differences between years and sites. (6) Picea mariana leader lengths are variable among the sites, but we found it difficult to find suitable trees and to be sure that we measured the correct bud scars; thus, we have less confidence in this measure. Based on these results we recommend a monitoring protocol of (a) sites with 5 permanent plots each with (b) 30 or 60 point-intercepts along a $300-\mathrm{cm}$ line transect followed by multivariate analysis, (c) two $1-\mathrm{m}^{2}$ plots non-destructively sampled annually for Rhododendron groenlandicum and Chamaedaphne calyculata annual growth, (d) Evernia mesomorpha sampled for chlorophyll/phaeophytin analysis, and (e) NPP of Sphagnum fuscum determined from 
cranked wires. Additionally, variation in many responses at the site level are correlated to patterns of $\mathrm{N}$ deposition in the oil sands area, suggesting that attributes of shrubs, the lichen Evernia mesomorpha and Sphagnum fuscum, are useful indicators of changes in $\mathrm{N}$, and to a lesser extent, $\mathrm{S}$ deposition.

Acknowledgments We are especially grateful to Jeremy Hartsock who led much of the field work. We are also thankful to Ava Alford, Kemar Jones, Derek Tollette, and Brian Widmer for assistance in the field; to Kimberli Scott, Melanie Vile (MAV) and Caitlyn Herron for Sphagnum growth measurements in the field; and to D. Tollette for 2019 chlorophyll analysis. We are pleased to acknowledge the very useful comments from a reviewer.

Funding Funding for this research was provided by the Department of Plant Biology, Southern Illinois University, to DHV and from the Oil Sands Monitoring Program (Grant \# 18GRAEM07 and amendments to RKW and MAV) and is a contribution to the Program, but does not necessarily reflect the position of the Program.

Compliance with ethical standards DHV designed the protocols and wrote most of the manuscript, $\mathrm{MH}$ provided the statistical analyses and graphics, SK carried much of the laboratory and early statistical analyses, RKW provided the Sphagnum growth data and analyses and $\mathrm{N}$ and $\mathrm{S}$ deposition data, all authors contributed to the field work. Data are available from the corresponding author upon request.

Conflict of interest The authors declare that they have no conflict of interest.

Open Access This article is licensed under a Creative Commons Attribution 4.0 International License, which permits use, sharing, adaptation, distribution and reproduction in any medium or format, as long as you give appropriate credit to the original author(s) and the source, provide a link to the Creative Commons licence, and indicate if changes were made. The images or other third party material in this article are included in the article's Creative Commons licence, unless indicated otherwise in a credit line to the material. If material is not included in the article's Creative Commons licence and your intended use is not permitted by statutory regulation or exceeds the permitted use, you will need to obtain permission directly from the copyright holder. To view a copy of this licence, visit http://creativecommons.org/licenses/by/4.0/.

\section{References}

ABMI (2017). ABMI species website manual. Alberta biodiversity monitoring institute. Version 2017-10-06. Abmi.ca
Arnon, D. I. (1949). Copper enzymes in isolated chloroplasts. Polyphenoloxidase in Beta vulgaris. Plant Physiol, 24, 115. https://doi.org/10.1104/pp.24.2.2.

Barnes, J. D., Balaguer, L., Manrique, E., Elvira, S., \& Davison, A. W. (1992). A reappraisal of the use of DMSO for the extraction of chlorophyll $a$ and $b$ in lichnes and higher plants. Environmental and Experimental Botany, 32, 85-100. https://doi.org/10.1016/0098-8472(92)90034-Y.

Belland, R. J., \& Vitt, D. H. (1995). Bryophyte vegetation patterns along environmental gradients in continental bogs. Ecoscience, 2, 395-407. https://doi.org/10.1080 /11956860.1995.11682308.

Berendse, F. N., van Breeman, N., Rydin, H., Buttler, A., Heijmans, M. M. P. D., Hoosbeek, M. R., Lee, J. A., Mitchell, E., Saarinen, T., Vasander, H., \& Wallen, B. (2001). Raised atmospheric $\mathrm{CO}_{2}$ levels and increased $\mathrm{N}$ deposition cause shifts in plant species composition and production in Sphagnum bogs. Global Change Biology, 7, 591-598. https://doi.org/10.1046/j.1365-2486.2001.00433. $\mathrm{x}$.

Berryman, S., Straker, J., Melaschenko, N., Berg, K., Watmough, S., McDonough, A., \& Bird, A. (2016). Ecological responses to five years of experimental nitrogen application in a jack pine stand. In Nitrogen critical loads five year final report, may 2016 final report (pp. 20-40). Edmonton: Cumulative Environmental Management Association.

Bobbink, R., \& Hettelingh, J.-P. (Eds.). (2011). Review and revision of empirical critical loads and dose-response relationships. Bilthoven: Coordination Centre for effects, National Institute for Public Health and the Environment (RIVM).

Bragazza, L., \& Limpens, J. (2004). Dissolved organic nitrogen dominates in European bogs under increasing nitrogen deposition. Global Biogeochemical Cycles, 18, GB4018. https://doi.org/10.1029/2004GB002267.

Bragazza, L., Limpens, J., Gerdol, R., Grosvernier, P., Hájek, M., Hájek, T., Hajkova, P., Hansen, I., Lacumin, P., Kutnar, L., Rydin, H., \& Tahvanainen, T. (2005). Nitrogen concentration and $15 \mathrm{~N}$ signature of ombrotrophic Sphagnum mosses at different $\mathrm{N}$ deposition levels in Europe. Global Change Biology, 11, 106-114. https://doi.org/10.1111/j.13652486.2004.00886.x.

Braun-Blanquet, J. (1932). Plant Sociology. (translated, revised, and edited by G. D. Fuller and H. S. Conard). New York: McGraw-Hill.

Bubier, J. L., Moore, T. R., \& Bledzki, L. A. (2007). Effects of nutrient addition on vegetation and carbon cycling in an ombrotrophic bog. Global Change Biology, 13, 1168-1186. https://doi.org/10.1111/j.1365-2486.2007.01346.x.

Bubier, J. L., Smith, R., Juutinen, S., Moore, T. R., Minocha, R., Long, S., \& Minocha, S. (2011). Effects of nutrient addition on leaf chemsitry, morphology, and photosynthetic capacity of three bog shrubs. Oecologia, 167, 355-368. https://doi. org/10.1111/J.1365-2486.2007.01346.X.

Canfield, R. (1941). Application of the line interception method in sampling range vegetation. Journal of Forestry, 39, 388394.

Clarke, K. R., \& Gorley, R. N. (2006). PRIMER v. 7. User manual/tutorial. Plymouth: PRIMER-E.

Clements, F. E. (1905). Research methods in ecology. Lincoln: University Publishing Co.. 
Clymo, R. S. (1970). The growth of Sphagnum: methods of measurements. Journal of Ecology, 58, 13-49. https://doi. org/10.2307/2258168.

Connolly, B. J., \& Grigal, D. F. (1983). Biomass estimations equations for wetland tall shrubs. Minnesota Forest Resources Notes, 84, 4.

Fenn, M. E., Poth, M. A., \& Arbaugh, A. J. (2002). A throughfall collection method using mixed bed ion exchange resin columns. Science World Journal, 2, 122-130. https://doi. org/10.1100/tsw.2002.84.

Fenn, M. E., Blubaugh, T., Alexander, D., \& Jones, D. (2003). Using ion exchange resins to monitor throughfall and bulk deposition to forests. USDA Forest Service, Pacific Southwest Research Station, www.fs.fed.us/psw/topics/air quality/resin collectors/fenn iermethods.pdf. Accessed $1 \overline{5}$ May 2020.

Fenn, M. E., Bytnerowicz, S. L., Schilling, S. L., \& Ross, C. S. (2015). Atmospheric deposition of nitrogen, sulfur and base cations in jack pine stands in the Athabasca Oil Sands Region., Alberta, Canada. Environmental Pollution, 196, 497-510.

Galloway, J. N., Townsend, A. R., Erisman, J. W., Bekunda, M., Cai, Z., Freney, J. R., Martinelli, L. A., Seitzinger, S. P., \& Sutton, M. A. (2008). Transformation of the nitrogen cycle: recent trends, questions, and potential solutions. Science, 320, 889-892. https://doi.org/10.1126/science.1136674.

Gilbert, O. L. (1986). Field evidence for an acid rain effect on lichens. Environmental Pollution, 40, 227-231. https://doi. org/10.1016/0143-1471(86)90097-8.

Glaser, P. H., \& Janssens, J. A. (1986). Raised bogs in eastern North America: transitions in surface patterns and stratigraphy. Canadian Journal of Botany, 64, 395-415. https://doi. org/10.1139/b86-056.

Goodall, D. W. (1953). Point-quadrat methods for analysis of vegetation. Australian Journal of Botany, 1, 457-461. https://doi.org/10.1071/BT9530457.

Gunnarsson, U., \& Rydin, H. (2000). Nitrogen fertilization reduces Sphagnum production in bog communities. New Phytologist, 147, 527-537. https://doi.org/10.1046/j.14698137.2000.00717.x.

Gunnarsson, U., Granberg, G., \& Nilsson, M. (2004). Growth, production and inter-specific competition in Sphagnum: Effects of temperature, nitrogen and sulphur treatments on a boreal mire. New Phytologist, 153, 349-359. https://doi. org/10.1111/j.1469-8137.2004.01108.x.

He, A., McDermid, G. J., Mustafizur Rahman, M., Strack, M., Saraswati, S., \& Xu, B. (2018). Developing allometric equations for estimating shrub biomass in a boreal fens. Forests, 9. https://doi.org/10.3390/19090569.

Hember, R. A. (2018). Spatially and temporally continuous estimates of annual total nitrogen deposition over North America, 1860-2013. Data in Brief, 17, 134-140. https://doi.org/10.1016/j.dib.2017.12.052.

Hoosbeek, N. R., van Breemen, N., Vasander, H., Buttler, A., \& Berendse, F. (2002). Potassium limits potential growth of bog vegetation under elevated atmospheric $\mathrm{CO}_{2}$ and $\mathrm{N}$ deposition. Global Change Biology, 8, 1130-1138. https://doi. org/10.1046/j.1365-2486.2002.00535.x.

JMP, Version Pro 14. SAS Institute Inc., Cary, NC. 1989-2019.

Johansson, O., Nordin, A., Olofosson, J., \& Palmqvist, K. (2010). Responses of epiphytic lichens to an experimental whole-tree nitrogen deposition gradient. New Phytologist, 188, 10751084. https://doi.org/10.1111/j.1469-8137.2010.03426.x.

Juutinen, S., Moore, T. R., Laine, A. M., Bubier, J. L., Tuitilla, E.S., de Young, A., \& Chong, M. (2015). Responses of the mosses Sphagnum capillifolium and Polytrichum strictum to nitrogen deposition in a bog: growth, ground cover, and $\mathrm{CO} 2$ exchange. Botany, 94, 127-138. https://doi.org/10.1139/cjb2015-0183.

Kanakidou, M., Myriokefalitakis, S., Daskalakis, N., Fanourgakis, G., Nenes, A., Baker, A. R., Tsigaridis, K., \& Mihalopoulos, N. (2016). Past, present, and future atmospheric nitrogen deposition. Journal of Atmospheric Sciences, 73, 20392047. https://doi.org/10.1175/JAS-D-15-0278.1.

Lamers, L. P. M., Bobbink, R., \& Roelofs, J. G. M. (2000). Natural nitrogen filter fails in polluted raised bogs. Global Change Biology, 6, 583-586. https://doi.org/10.1046/j.13652486.2000.00342.x.

Limpens, J., \& Berendse, F. (2003). Growth reduction of Sphagnum magellanicum subjected to high nitrogen deposition: the role of amino acid nitrogen concentration. Oecologia, 135, 339-345. https://doi.org/10.1007/s00442003-1224-5.

Limpens, J., Berendse, F., \& Klees, H. (2003). N deposition affects $\mathrm{N}$ availability in interstitial water growth of Sphagnum and invasion of vascular plants in bog vegetation. New Phytologist, 157, 339-347. https://doi.org/10.1046/j.14698137.2003.00667.x.

McCune, B., \& Grace, J. B. (2002). Analysis of ecological communities. Glenneden Beach: MjM Software.

Pardo, L. H., Fenn, M. E., Goodale, C. L., Geiser, L. H., Driscoll, C. T., Allen, E. B., et al. (2011). Effects of nitrogen deposition and empirical nitrogen critical loads for ecoregions of the United States. Ecological Applications, 21, 3049-3082. https://doi.org/10.1890/10-2341.1.

Phillips, E. A. (1959). Methods of vegetation study. New York: Holt, Rinehart, and Winston.

Poulin, M., Andersen, R., \& Rochefort, L. (2013). A new approach for tracking vegetation change after restoration: a case study with peatlands. Restoration Ecology, 21(3), 363-371. https://doi.org/10.1111/j.1526-100X.2012.00889.x.

Ra, H. S. Y., Geiser, L. H., \& Crang, R. F. E. (2005). Effects of season and low-level air pollution on physiology and element content of lichens from the U.S. Pacific Northwest. Science of the Total Environment, 343, 155-167. https://doi. org/10.1016/j.scitotenv.2004.10.003.

Rochefort, L., Vitt, D. H., \& Bayley, S. E. (1990). Growth, production and decomposition dynamics of Sphagnum under natural and experimentally acidified conditions. Ecology, 71, 1986-2000. https://doi.org/10.2307/1937607.

Rochefort, L., Isselin-Nondedeu, F., Boudreau, S., \& Poulin, M. (2013). Comparing survey methods for monitoring vegetation change through time in a restored peatland. Wetlands Ecology and Management, 21(1), 71-85. https://doi. org/10.1007/s11273-012-9280-4.

Ronen, R., \& Galun, M. (1984). Pigment extraction from lichens with dimethyl sulfoxide (DMSO) and estimation of chlorophyll degradation. Environmental and Experimental Botany, 24, 239-245. https://doi.org/10.1016/0098-8472(84)900042.

Ruuhijärvi, R. (1983). The Finnish mire types and their regional distribution. In A. J. P. Gore (Ed.), Ecosystems of the world 
$4 B$ mires: swamp bog, fen and moor regional studies (pp. 47-67). Amsterdam-Oxford-New York: Elsevier Scientific Publishing Co..

SAS, Version 9.4, SAS Institute Inc., Cary, NC. 1989-2019.

Sjörs, H. (1983). Mires of Sweden. In A. J. P. Gore (Ed.), Ecosystems of the world $4 B$ mires: swamp bog, fen and moor regional studies (pp. 69-94). Amsterdam-Oxford-New York: Elsevier Scientific Publishing Co..

Tait, M. A., \& Hik, D. S. (2003). Is dimethylsulfoxide a reliable solvent for extracting chlorophyll under field conditions? Photosynthesis Research, 78, 87-91. https://doi.org/10.1023 /A: 1026045624155.

Van Dobben, H. J., Wolterbeek, H. Y., Warnelink, G. W. W., \& Ter Braack, C. J. F. (2001). Relationship between epiphytic lichens, trace elements, and gaseous atmospheric pollutants. Environmental Pollution, 112, 163-169. https://doi. org/10.1016/S0269-7491(00)00121-4.

Vitt, D. H. (2006). Functional characteristics and indicators of boreal peatlands. In R. K. Wieder \& D. H. Vitt (Eds.), Boreal peatland ecosystems (pp. 9-24). Berlin-HeidelburgNew York: Springer-Verlag.

Vitt, D. H. (2007). Estimating ground layer net primary production in tundra, peatlands, and forests. In T. Fahey (Ed.), Principles and standards for measuring net primary productivity in long-term ecological studies (pp. 82-105). Oxford: Oxford Press.

Vitt, D. H., Li, Y., \& Belland, R. J. (1995a). Patterns of bryophyte diversity in peatlands of continental western Canada. The Bryologist, 98, 218-227. https://doi.org/10.2307/3243306.

Vitt, D. H., Halsey, L. A., Thormann, M. N., \& Martin, T. (1995b). An overview of peatland resources in the natural regions and subregions of Alberta. Edmonton: Alberta Peat Task Force, Edmonton and NCE-SFMN, University of Alberta.

Vitt, D. H., Halsey, L. A., Bauer, I. E., \& Campbell, C. (2000). Spatial and temporal trends of carbon sequestration in peatlands of continental western Canada through the
Holocene. Canadian Journal of Earth Sciences, 37, 683693. https://doi.org/10.1139/e99-097.

Wieder, R. W., Scott, K. D., Kamminga, K., Vile, M. A., Vitt, D. H., Bone, T., Xu, B., Benscoter, B. W., \& Bhatti, J. S. (2009). Post-fire carbon balance in boreal bogs of Alberta, Canada. Global Change Biology, 15, 63-82. https://doi.org/10.1111 /j.1365-2486.2008.01756.x.

Wieder, R. K., Vile, M., Scott, K., Albright, C. M., McMillen, K., Vitt, D. H., \& Fenn, M. (2016a). Differential effects of high atmospheric deposition on bog plant/lichen tissue and porewater chemistry across the Athabasca oil sands region. Environmental Science and Technology, 50, 12630-12640. https://doi.org/10.1021/acs.est.6b03109.

Wieder, R. K., Vile, M., Albright, C. M., Scott, K., Vitt, D. H., Quinn, J. C., \& Burke-Scoll, M. (2016b). Effects of altered atmospheric nutrient deposition from Alberta oil sands development on Sphagnum fuscum growth and C, N and S accumulation in peat. Biogeochemistry, 129, 1-19. https://doi.org/10.1007/s10533-016-0216-6.

Wieder, R. K., Vitt, D. H., Vile, M. A., Graham, J. A., Hartsock, J. A., Fillingim, H., House, M., Quinn, J. C., Scott, K. D., Petix, M., \& McMillen, K. J. (2019). Experimental nitrogen addition alters structure and function of a boreal bog: critical load and thresholds revealed. Ecological Monographs, 89(3), e01371. https://doi.org/10.1002/ecm.1371.

Wiedermann, M. M., Gunnarsson, U., Ericson, L., \& Nordin, A. (2008). Ecophysiological adjustment of two Sphagnum species in response to anthropogenic nitrogen deposition. New Phytologist, 181, 208-217. https://doi.org/10.1111/j.14698137.2008.02628.x.

Publisher's note Springer Nature remains neutral with regard to jurisdictional claims in published maps and institutional affiliations. 